\title{
Perspectives on miRNAs Targeting DKK1 for Developing Hair Regeneration Therapy
}

\author{
Dimitri Papukashvili + ${ }^{\circ}$, Nino Rcheulishvili ${ }^{+}(\mathbb{D}$, Cong Liu, Fengfei Xie, Deependra Tyagi, Yunjiao He * \\ and Peng George Wang *(i)
}

School of Medicine, Southern University of Science and Technology, Shenzhen 518000, China; dimitri@sustech.edu.cn (D.P.); nino@sustech.edu.cn (N.R.); 11930759@mail.sustech.edu.cn (C.L.); xieff@mail.sustech.edu.cn (F.X.); deependrat@sustech.edu.cn (D.T.)

* Correspondence: heyj@sustech.edu.cn (Y.H.); wangp6@sustech.edu.cn (P.G.W.); Tel.: +86-135-3765-7996 (Y.H.); +86-0755-8801-5584 (P.G.W.)

+ These authors contributed equally to this work.

Citation: Papukashvili, D.; Rcheulishvili, N.; Liu, C.; Xie, F.; Tyagi, D.; He, Y.; Wang, P.G. Perspectives on miRNAs Targeting DKK1 for Developing Hair Regeneration Therapy. Cells 2021, 10, 2957. https://doi.org/10.3390/ cells10112957

Academic Editor: Ajit Vikram

Received: 10 October 2021

Accepted: 26 October 2021

Published: 30 October 2021

Publisher's Note: MDPI stays neutral with regard to jurisdictional claims in published maps and institutional affiliations.

\begin{abstract}
Androgenetic alopecia (AGA) remains an unsolved problem for the well-being of humankind, although multiple important involvements in hair growth have been discovered. Up until now, there is no ideal therapy in clinical practice in terms of efficacy and safety. Ultimately, there is a strong need for developing a feasible remedy for preventing and treating AGA. The Wnt/ $\beta$-catenin signaling pathway is critical in hair restoration. Thus, AGA treatment via modulating this pathway is rational, although challenging. Dickkopf-related protein 1 (DKK1) is distinctly identified as an inhibitor of canonical Wnt $/ \beta$-catenin signaling. Thus, in order to stimulate the Wnt $/ \beta$-catenin signaling pathway, inhibition of DKK1 is greatly demanding. Studying DKK1-targeting microRNAs (miRNAs) involved in the Wnt/ $\beta$-catenin signaling pathway may lay the groundwork for the promotion of hair growth. Bearing in mind that DKK1 inhibition in the balding scalp of AGA certainly makes sense, this review sheds light on the perspectives of miRNA-mediated hair growth for treating AGA via regulating DKK1 and, eventually, modulating Wnt/ $\beta$-catenin signaling. Consequently, certain miRNAs regulating the Wnt/ $\beta$-catenin signaling pathway via DKK1 inhibition might represent attractive candidates for further studies focusing on promoting hair growth and AGA therapy.
\end{abstract}

Keywords: miRNA; AGA; DKK1; Wnt/ $\beta$-catenin; hair

\section{Introduction}

Hair growth is a relatively complex process. The human hair cycle comprises three main phases: anagen, catagen, and telogen [1]. Anagen is an active growing phase of hair and lasts for the longest period (up to eight years). During the catagen phase (2-3 weeks), hair follicles (HF) undergo regression. This is followed by the telogen, which is the resting phase ( $\sim 3$ months) [2]. Ultimately, hair shedding takes place, that may be considered as the fourth phase-exogen $[3,4]$.

Hair growth is controlled and influenced by various endogenous factors, including intracellular and intercellular signaling molecules. Some of the influencing factors have inhibitory and some stimulatory effects on the hair cycle. The initiation of the anagen phase is inhibited by the activation of bone morphogenetic proteins (BMP) as well as transforming growth factor $\beta$ (TGF- $\beta$ ) signaling [2]. On the other hand, the onset of Wnt $/ \beta$-catenin [5-7] or sonic hedgehog (SHH) signaling pathways stimulate hair growth and anagen entry [2,8]. In case of the wingless and integrated-1 (Wnt)-mediated hair regrowth, hypo-phosphorylated $\beta$-catenin is stabilized, which triggers the interaction between $\beta$-catenin and T-cell factor/lymphoid enhancer factor (TCF/LEF) in the nucleus. As a result, growth-promoting genes are trans-activated and hair regrowth occurs [2]. Based on the available data, out of all the pathways implicated in the hair cycle, we assume that the Wnt/ $\beta$-catenin signaling represents the key factor in hair growth regulation [9], 
as dihydrotestosterone (DHT) - a hormone that is upregulated in androgenetic alopecia (AGA) and causes the hair loss-impairs this signaling pathway [10]. The main identified inhibitors of this signaling pathway are dickkopf-related protein 1 (DKK1), secreted frizzled-related protein 2 (SFRP2), and sclerostin (SOST). As Wnt/ $\beta$-catenin signaling is involved in numerous biological processes, each of the mentioned inhibitors features certain functions. Hence, the dysregulation of the levels of any of these inhibiting proteins affects the particular physiological pathogenesis, including AGA. DKK1 is a natural inhibitor of $W n t$, and strongly suppresses the Wnt/ $\beta$-catenin signaling pathway via disrupting the Wnt-induced frizzled-low-density lipoprotein receptor-related proteins (LRP) 5/6 complex formation. This adversely impacts HF morphogenesis and, thus, influences the hair cycle [11]. Indeed, the study has demonstrated that DKK1 triggers anagen-to-catagen transition when injected in the skin of C57BL/ 6 mice. Moreover, injection of the anti-DKK1 neutralizing antibody resulted in the delay of catagen progression [12]. Interestingly, the human study showed that a significantly high concentration of tissue DKK1 was present in patients with AGA compared to the healthy controls [11]. DHT is known to negatively interfere with the normal hair cycle via driving the HF in the balding scalp to catagen entry and inhibiting the growth of keratinocytes that takes place through DKK1 implication [13].

According to the aforementioned evidence, it is prudent to postulate that inhibition of DKK1 - a canonical Wnt/ $\beta$-catenin signaling inhibitor-is one of the key factors to promote hair growth and develop a sustainable remedy for AGA. Indeed, there are certain microRNAs (miRNAs) that target DKK1 and are involved in hair growth-related pathways. Thereby, in this review, the possible application of miRNAs for AGA therapy via targeting upregulated DKK1 expression in the balding scalp and activating Wnt/ $\beta$-catenin is postulated.

\section{The Importance of Wnt/ $\beta$-Catenin Signaling in Hair Growth}

The canonical Wnt/ $\beta$-catenin signaling is one of the most studied pathways in biology as it is responsible for a number of vital physiological processes in the body [14]. Controlling the cell fate, including cell proliferation, differentiation [15], normal functioning, apoptosis [16], and maintaining tissue homeostasis, as well as affecting cancer development $[15,17-19]$, are among them $[15,17,20-23]$. Interestingly, apart from the mentioned involvements in various physiological conditions, dysregulation of Wnt/ $\beta$-catenin signaling is strongly associated with the development of AGA - a dermatological disorder whereby the hair is abnormally shed from the skin where it normally should be presented. Particularly, it is suppressed in AGA [13,22,24-27]. Indeed, various Wnt proteins play a substantial role in the hair growth cycle [2]. Wnt proteins such as Wnt3a [28-30] and Wnt10b $[6,31]$ are essential for HF growth and hair regeneration. In this regard, finding the best strategy for reactivation of the Wnt/ $\beta$-catenin signaling pathway in people with alopecia has emerged as an area of study. For a better understanding of how this pathway functions in normal conditions and AGA, the molecular mechanism is addressed here: The hair starts growing from the bottom of HFs-mini-organs that are integrated in the epidermis and anchor each of the hairs into the skin with the hair bulb, that forms the base of the HF. The HFs play a pivotal role in hair cycling regulation, together with the whole well-organized complex of structures that assembles the HF itself [32,33]. The cells in the hair bulb are divided and form a hair shaft. Hair bulbs surround dermal papilla (DP) cells that are the key components in the molecular crosstalk between the mesenchymal and neighboring epithelial cells during the hair cycle [4]. The Wnt/ $\beta$-catenin signaling pathway plays an indispensable role in regulating HF morphogenesis during the embryonic stage and adult life [6,22,34-36].

During the canonical Wnt/ $\beta$-catenin signaling, Wnt ligands (Wnt1a, 2, 3a, 4, 5a, 7b, $10 \mathrm{a}$, and $10 \mathrm{~b}$ ) bind the frizzled receptor and LRP5/6 co-receptor outside of the plasma membrane [2,16], which induces the phosphorylation of LRP5/6 from the intracellular part of the plasma membrane by two kinases-glycogen synthase kinase $3 \beta$ (GSK-3 $\beta$ ) and casein kinase 1 (CK1) - which are the part of the destruction complex. This is followed 
by the recruitment of protein dishevelled (DVL), which binds to the frizzled receptor endo-domain. As a result, the destruction complex is inactivated, which protects $\beta$-catenin from targeting by the proteasome [37]. Consequently, hypo-phosphorylated $\beta$-catenin is stabilized and accumulated in the cytoplasm [16]. Stabilized $\beta$-catenin is able to translocate into the nucleus, where it binds to TCF/LEF via displacing the transcriptional repressor Groucho [38]. A transcriptional complex is formed, and the transcription of several Wnttarget genes is activated [16,38]. On the other hand, when Wnt signaling is off, $\beta$-catenin is then phosphorylated by GSK-3 $\beta$ and CK1. Except for GSK-3 $\beta$ and CK1, the destruction complex consists of two other components-scaffolding protein AXIN and adenomatous polyposis coli (APC) protein. The phosphorylated $\beta$-catenin then undergoes ubiquitination, which makes it a target of the proteasome. When Wnt/ $\beta$-catenin signaling is off, $\beta$-catenin becomes unstable and undergoes proteasomal degradation $[37,39]$. As a result, the transcriptional complex is not formed, and Groucho remains bound to TCF/LEF. Hence, the gene expression is suppressed [16,38]. When the DKK1 level is upregulated, it binds to LRP5/6, which suppresses the whole cascade of the signaling pathway, leading to the inhibition of HF development and, consequently, hair growth [31] (Figure 1). As previously mentioned, DKK1 overexpression is evidenced in the scalp of patients with AGA. Thus, it represents the key protein in the development of AGA [40].

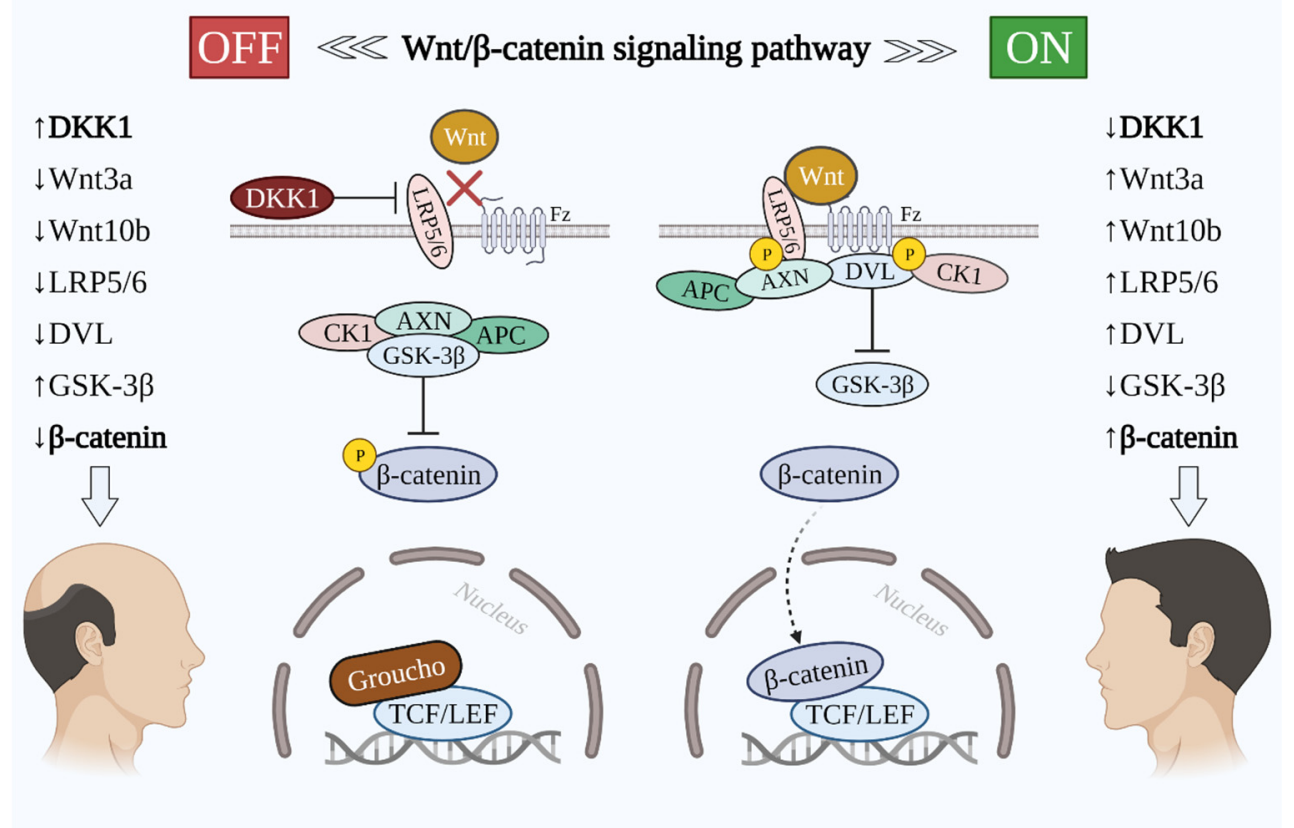

Figure 1. The implication of key molecules in the Wnt/ $\beta$-catenin signaling pathway in hair loss and growth. Wnt/ $\beta$-catenin signaling pathway OFF (on the left side): DKK1 inhibits LRP5/6 and does not allow Wnt proteins to activate the signaling pathway. Destruction complex inhibits $\beta$-catenin and its translocation into the nucleus is prevented. Transcription of Wnt-targeted genes is hindered. Wnt/ $\beta$-catenin signaling pathway ON (on the right side): Wnt binds to Fz and LRP5/6, which is followed by the phosphorylation of LRP5/ 6 intracellularly that leads to the DVL recruitment to Fz. $\beta$-catenin is then translocated into the nucleus and displaces Groucho. Transcription of Wnt-targeted genes takes place. Abbreviations: DKK1, dickkopf-related protein 1; Wnt, wingless and integrated-1; Fz, frizzled; LRP5/6, low-density lipoprotein receptor-related proteins 5/6; AXN, axin; GSK3- $\beta$, glycogen synthase kinase $3 \beta$; CK1, casein kinase 1; DVL, dishevelled; APC, adenomatous polyposis coli; TCF/LEF, T-cell factor/lymphoid enhancer factor. 
Although SFRP2 is also considered to be the inhibitor of the Wnt/ $\beta$-catenin signaling pathway, some conflicting data exist. Kwack et al. have studied the influence of SFRP2 on cultured human DP cells obtained from patients undergoing hair transplantation via punch biopsy. The results showed that treatment with recombinant human SFRP2 remarkably increased Wnt / $\beta$-catenin signaling [41]. Thus, DKK1 appears to be the key target molecule for studies that will focus on strategies of Wnt/ $\beta$-catenin signaling augmentation in DP cells of AGA. Interestingly, a number of miRNAs is involved in the regulation of hair growth [42], and impairment of Wnt/ $\beta$-catenin signaling negatively affects normal hair cycling [2]. This raises the idea of using certain miRNAs for modulating hair growth via regulating the $\mathrm{Wnt} / \beta$-catenin signaling pathway.

\section{DKK1 Implication in AGA}

\subsection{DHT-Induced DKK1-Mediated AGA}

DKK genes encode secreted proteins that regulate the Wnt/ $\beta$-catenin signaling pathway by antagonizing it [43]. Remarkably, DHT and DKK1 levels are positively correlated. In the body, 5 alpha-reductase $(5 \alpha \mathrm{R})$ converts testosterone into DHT. It acts like an inhibitor for the growth of outer root sheath (ORS) cells that disrupts the normal hair growth process. Moreover, the anti-DKK1 neutralizing antibody substantially decreased the inhibition of ORS cells' growth. As previously mentioned, DKK1 concentration is increased in the bald scalp of AGA patients compared with the haired scalp of AGA patients [10,40]. Besides, DHT-influenced DKK1 augmentation has been demonstrated to enhance the apoptosis of keratinocytes in vitro [10]. It can be presumed that DKK1 plays an important role in AGA development. Indeed, the study demonstrated that DKK1 is involved in AGA pathology. In the study, recombinant human DKK1 treatment triggered the hair cycle to enter the catagen phase earlier than normal in C57BL/ 6 mice, which resulted in the decrease of HF length. Contrarily, treatment with the neutralizing DKK1 antibody led to the increased HF length and delayed the shift of anagen to catagen. The recombinant DKK1 has inhibited the canonical Wnt/ $\beta$-catenin signaling pathway that promotes hair growth in normal physiological condition. As a result of $\mathrm{Wnt} / \beta$-catenin signaling suppression, the anagen phase is shortened and the apoptosis of follicular keratinocytes takes place [12].

\subsection{Negative Influence of DKK1 on Hair Growth}

DKK1 exhibits a dual role in the normal hair cycle. On the one hand, DKK1 induces attenuation of the hair growth process by inhibiting Wnt/ $\beta$-catenin signaling via the LRP5 / 6 co-receptor and, on the other hand, it promotes apoptosis of keratinocytes, which are key cells involved in hair growth $[10,40]$. Hence, AGA, also known as male pattern baldness (MPB), is the consequence of the abovementioned dual mechanism of DKK1 in human HFs. Indeed, a case-control study that included 20 male AGA and 20 male alopecia areata (AA) patients has demonstrated that the immunohistochemical expression of DKK1 was remarkably increased in lesional scalp biopsies of both AGA and AA patients [40]. Additionally, DKK1 decreases the HF enlargement and width of the hairs [31]. Markedly, DKK1 levels are evidenced to be elevated along with age [44,45], whilst age is also related to the development of AGA [46] (Figure 2). Besides, AGA is manifested severely in the obese population $[47,48]$. Concomitantly, DKK1 is hypothesized as a potential biomarker in obesity $[49,50]$. Additionally, Kim et al. have demonstrated that treatment with minoxidil—a common drug for hair-loss—downregulated DKK1 and TGF- $\beta$ in human keratinocyte cells [51]. 


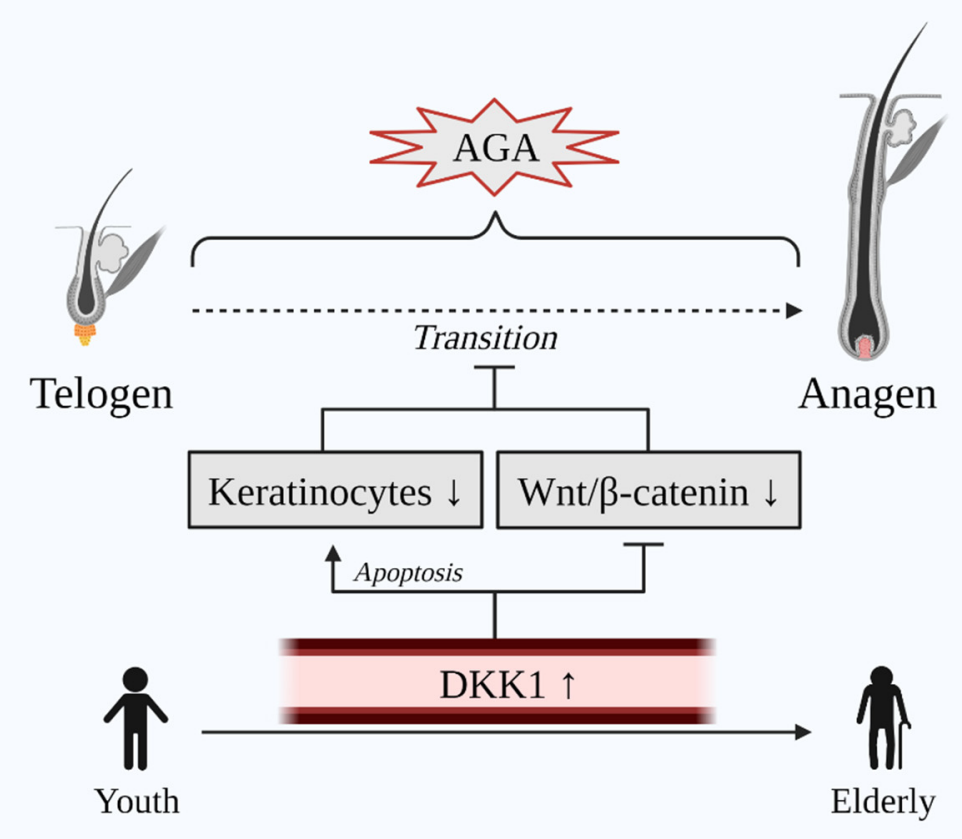

Figure 2. Dual unfavorable role of DKK1 on hair growth. The transition of telogen to anagen is delayed in AGA. DKK1 is upregulated in the scalp of AGA as well as in the serum of the elderly population where AGA is common. Elevated DKK1 levels induce the apoptosis of keratinocytes and inhibit Wnt/ $\beta$-catenin signaling. Abbreviations: AGA, androgenetic alopecia; DKK1, dickkopfrelated protein 1 ; Wnt, wingless and integrated-1.

\subsection{Molecular Mechanism of Wnt/ß-Catenin Signaling Inhibition by DKK1}

DKK1 inhibits Wnt/ $\beta$-catenin signaling via binding to LRP5 and LRP6, which prevents the interaction between Wnt and the other transmembrane receptor frizzled [52]. The inhibition is enhanced via the synergistic effect of DKK1 and its single transmembrane receptors kremens (KRM1 and KRM2) that promote the endocytosis of LRPs. Cselenyi and Lee have proposed that KRMs-dependent activation/inhibition of Wnt/ $\beta$-catenin signaling depends on the presence of DKK1 [20,53]. In case of DKK1 presence, LRP5/6, DKK1, and KRM interact with each other and generate a complex that is endocytosed. Consequently, LRP5/ 6 is reduced in the plasma membrane; thus, Wnt/ $\beta$-catenin signaling is suppressed, $\beta$-catenin is degraded, and the hair growth-related gene expression does not take place [54]. The inhibitive role of DHT-induced secreted DKK1 on the Wnt/ $\beta$-catenin signaling pathway is shown in Figure 3.

\subsection{Compounds Capable to Inhibit DKK1 Expression and Promote Hair Growth}

According to the abovementioned information, the study of DKK1 inhibition strategies is an important tool for maintaining the $\mathrm{Wnt} / \beta$-catenin signaling within the normal range. Indeed, some studies investigated the effect of certain natural compounds on the canonical Wnt/ $\beta$-catenin signaling pathway for promoting hair growth. Zhou et al. have observed the impact of morroniside - a natural compound found in cornelian cherry-on the $\mathrm{Wnt} / \beta$-catenin signaling pathway in cultured human ORS cells. In their results, morroniside indeed increased the proliferation of cells as well as the concentration of $\beta$-catenin. Concomitantly, the outcome of morroniside treatment was retrieved by the influence of DKK1 [52]. Another natural compound, vitexin, is also found to significantly increase the human dermal papilla cells' (HDPCs) proliferation in a concentration-dependent fashion. Additionally, Luo et al. have demonstrated that in vitexin-treated HDPCs, the $\beta$-catenin level was upregulated while the DKK1 level was substantially lowered [55]. Aside from 
that, Panax ginseng extract exhibited proliferation of ORS keratinocytes, inhibition of apoptosis, and revealed the opposite effect of DKK1 in human hair organ culture [56]. One more natural compound costunolide activates $\mathrm{Wnt} / \beta$-catenin and $\mathrm{SHH}$, while it inhibits TGF- $\beta$ /SMAD and BMP signaling pathways in HFs, and hence, stimulates hair growth [57]. The functional components of Ginkgo biloba — ginkgolide B and bilobalide—are known as agents that can aid in hair growth. Interestingly, these two compounds are evidenced to be associated with Wnt/ $\beta$-catenin signaling activation via inhibition of DKK1 expression levels in the cytoplasm and, thus, upregulation of nuclear $\beta$-catenin and its messenger RNA (mRNA) concentration [58]. The antidepressant tianeptine is also evidenced to stimulate hair shaft elongation, and hence hair growth, via inhibiting DKK1 and delaying the premature transition from anagen to catagen in MPB [59]. All these studies claim that the abovementioned natural compounds promote hair growth via inhibiting DKK1.

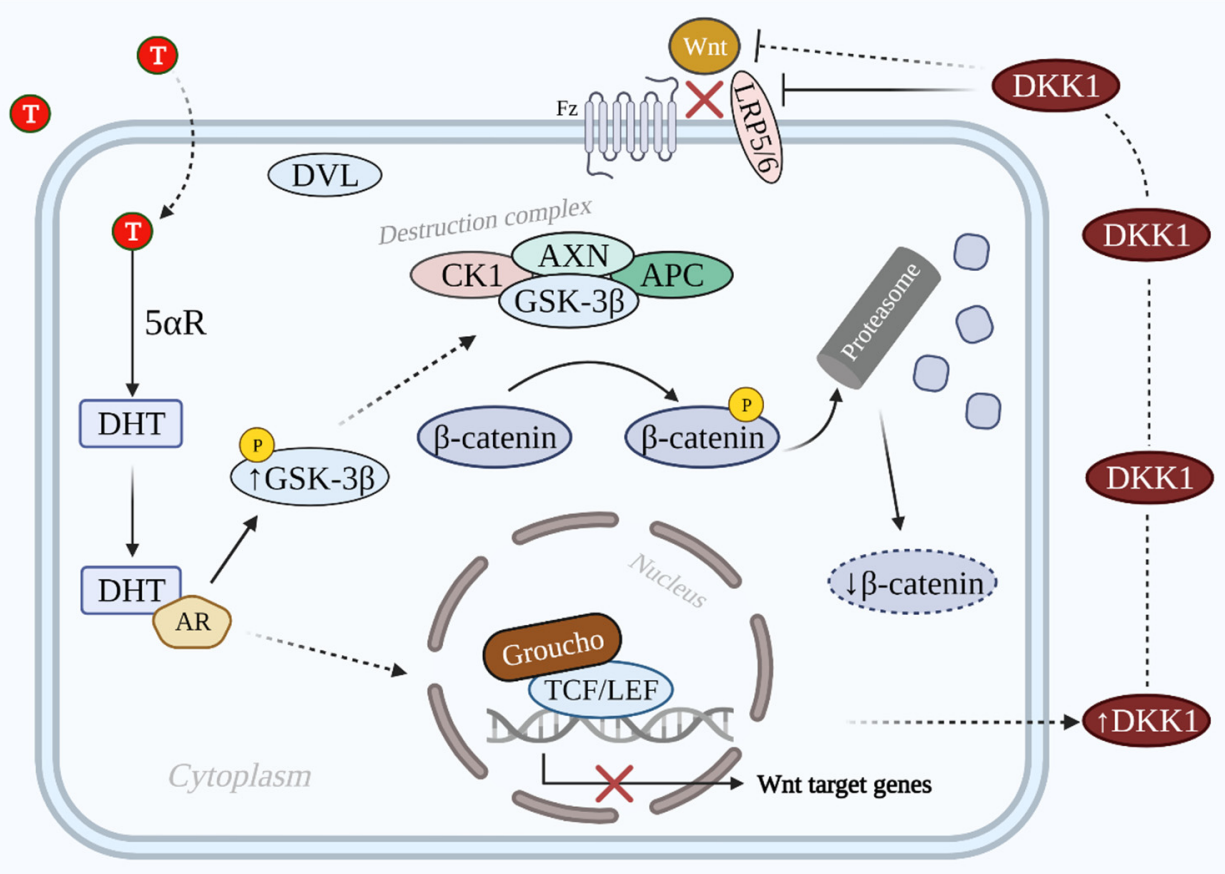

Figure 3. Illustration of Wnt/ $\beta$-catenin signaling pathway inhibition by DKK1 in AGA. In the AGA population the T level is elevated. T is converted into DHT by $5 \alpha R$, which binds to AR and prevents the dephosphorylation of GSK-3 $\beta$. GSK-3 $\beta$ induces the phosphorylation of $\beta$-catenin via the destruction complex. Phosphorylated $\beta$-catenin is degraded by the proteasome. On the other hand, DKK1 is also secreted that antagonizes Wnt/ $\beta$-catenin signaling via LRP5/6 inhibition. As a result, the Wnt/ $\beta$-catenin signaling pathway is inactivated and target genes are not expressed. Abbreviations: T, testosterone; DHT, dihydrotestosterone; $5 \alpha \mathrm{R}, 5$ alpha-reductase; AR, androgen receptor; DKK1, dickkopf-related protein 1; Wnt, wingless and integrated-1; Fz, frizzled; LRP5/6, lowdensity lipoprotein receptor-related proteins $5 / 6$; GSK-3 $\beta$, glycogen synthase kinase $3 \beta$; CK1, casein kinase 1; DVL, dishevelled; APC, adenomatous polyposis coli; TCF/LEF, T-cell factor/lymphoid enhancer factor.

\section{4. miRNAs Targeting DKK1 Expression}

miRNA was first identified in 1993 by Victor Ambros and colleagues, who found a short RNA molecule Lin-4 of 22-61 nucleotides in C. elegans that could downregulate the level of Lin-14 protein mRNA [60]. Seven years after the discovery, the first human-encoded miRNA Let-7 was described [61]. Currently, more than 3000 miRNAs are known to be present in the human genome and involved in numerous biological processes in almost all body fluids [62,63]. In 2013, the first miRNA mimic MRX34 (mimic of endogenous miR-34 that suppresses oncogenesis) entered into the clinical trials [64]. Currently, several miRNA 
drugs are in phase 1 or 2 of development $[65,66]$. However, up until now, there is no miRNA mimic approved by the Food and Drug Administration (FDA) [66]. On the other hand, there are already 3 small (short)-interfering RNA (siRNA)-based FDA-approved drugs, Patisiran [67], Givosiran [68], and Lumasiran [69], while the rest are in phase 3, 2, or 1 of clinical trials [66]. Given that it took 14 years since the initiation of the very first clinical trial (2004) [70] for siRNA to go to commercialization [71,72], it should not be long until the first miRNA mimic gains FDA approval. However, difficulties mainly regarding the delivery of miRNAs need to be overcome and the mechanisms of certain miRNAs should be fully understood.

Importantly, miRNAs play a crucial role in hair growth regulation [73]. They are involved in HF development as well as in DP cell proliferation. However, despite the increasing number of studies that demonstrate a critical role of miRNAs in skin regeneration, the molecular mechanisms are still not fully understood [74]. Some miRNAs that are implicated in hair morphogenesis have a positive while some have a negative impact on hair growth, e.g., one study showed that miR-214 targets $\beta$-catenin and modulates Wnt/ $\beta$-catenin signaling, and hence inhibits hair growth development [75]. On the other hand, other miRNAs, such as miR-218-5p, are related to inhibition of SFRP2 that represents the antagonist of the Wnt/ $\beta$-catenin signaling pathway and, thus, promotes hair growth [76,77]. As stated above, the level of DKK1 in the scalp of AGA patients is significantly higher [40]. Besides, DKK1 is already evidenced to inhibit the Wnt/ $\beta$-catenin signaling, which results in hair miniaturization and growth suppression [78]. There are miRNAs that target DKK1, e.g., miR-335-5p is downregulated while DKK1 protein levels are increased in TNF- $\alpha$-treated osteoblasts [79]. DKK1 is silenced by miRNAs including miR-335-5p at an early stage of osteogenic differentiation, and on the contrary, miRNA levels are decreased at a later stage of differentiation while DKK1 levels are upregulated. This points out the complex role of miRNAs in biological processes [80]. Besides, Michel et al. have demonstrated that the expression of Wnt antagonist SFRP2 mRNA was increased while the expression of another inhibitor DKK1 mRNA was not altered in scalp biopsies of AGA patients [81]. This fact might be rationalized with the involvement of certain miRNAs that target DKK1 mRNA, and the translation to protein is circumvented. Accordingly, developing the miRNA-based approach to inhibit DKK1 is certainly reasonable. The miRNAs that inhibit DKK1 expression in different health conditions/biological processes are presented in Table 1. 
Table 1. Recent studies referring to miRNAs that directly target DKK1 and the association with certain disorders/biological processes.

\begin{tabular}{|c|c|c|c|c|c|c|c|}
\hline miRNA & $\begin{array}{c}\text { Disorder/Biological } \\
\text { Process }\end{array}$ & miR Level & $\begin{array}{l}\text { DKK1 Relative } \\
\text { Expression }\end{array}$ & $\mathrm{miR}$ & ed Binding Site in $3^{\prime}$ UTR of DKK1 & Study Type & Ref. \\
\hline miR-1-3p & $\begin{array}{l}\text { Oral squamous cell } \\
\text { carcinoma }\end{array}$ & $\downarrow$ & $\uparrow$ & $\begin{array}{l}\text { DKK1 3' UTR } \\
\text { miR-1-3p }\end{array}$ & $\begin{array}{l}\text { 5'...GUGGUUUCAGUUAAGCAUUCCAAA...3' } \\
\text { 3' | I | || || | }\end{array}$ & in vitro & [82] \\
\hline miR-9-5p & $\begin{array}{c}\text { Dopaminergic neuron } \\
\text { differentiation }\end{array}$ & $\mathrm{N} / \mathrm{A}$ & $\downarrow$ & $\begin{array}{l}\text { DKK1 3' UTR } \\
\text { miR-9-5p }\end{array}$ & $\begin{array}{l}\text { 5' ...ATATGTTTAAAGATGATCAGAGA... 3' } \\
\text { 3' }{ }^{\prime} \text { AGTATGTCGATCTATTGGTTTCT }{ }^{\prime}\end{array}$ & in vitro & [83] \\
\hline $\operatorname{miR}-31$ & Breast cancer & $\downarrow$ & $\uparrow$ & $\begin{array}{l}\text { DKK1 3' UTR } \\
\text { miR-31 }\end{array}$ & $\begin{array}{l}\text { 5'...AGAAUGUAACACUUCUCUUGCCA... 3' } \\
|:||||:||||||| \mid \\
\text { 3' GUCGAUACGGU-CGUAGAACGGA }\end{array}$ & in vitro & [85] \\
\hline miR-33a-5p & Esophageal cancer & $\downarrow$ & $\uparrow$ & $\begin{array}{l}\text { DKK1 3' UTR } \\
\text { miR-33a-5p }\end{array}$ & $\begin{array}{l}\text { 5' ...UGGCACUUACCUGUAAAUGCAAU... 3' } \\
\text { 3' } \quad \text { ACGUUACGUUGAUGUUACGUG 5' }\end{array}$ & $\begin{array}{l}\text { in vivo } \\
\text { in vitro }\end{array}$ & [86] \\
\hline miR-101-3p & Osteogenic differentiation & $\uparrow$ & $\downarrow$ & $\begin{array}{l}\text { DKK1 3' UTR } \\
\text { miR-101-3p }\end{array}$ & $\begin{array}{l}\text { 5'... UGAUUGCAGUAAAUUACUGUA... 3' } \\
\text { 3' AAGUCAAUAGUGUCAUGACAU }\end{array}$ & in vitro & [88] \\
\hline miR-103a-3p & Osteogenic differentiation & $\uparrow$ & $\downarrow$ & $\begin{array}{l}\text { DKK1 3' UTR } \\
\text { miR-103a-3p }\end{array}$ & 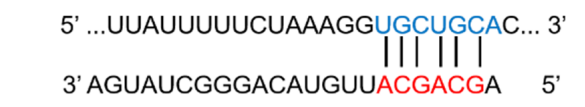 & in vitro & [89] \\
\hline miR-107 & Osteosarcoma & $\downarrow$ & $\uparrow$ & $\begin{array}{l}\text { DKK1 3' UTR } \\
\text { miR-107 }\end{array}$ & $\begin{array}{l}\text { 5'...UUAUUUUUCUAAAGGUGCUGCAC... 3' } \\
\text { 3' ACUAUCGGGACAUGUUACGACGA }\end{array}$ & in vitro & [90] \\
\hline miR-130b-3p & Melanoma & $\uparrow$ & $\downarrow$ & $\begin{array}{l}\text { DKK1 3' UTR } \\
\text { miR-130b-3p }\end{array}$ & $\begin{array}{l}\text { 5'...UUUUUCUAAAGGUGCUGCACUG... 3' } \\
\qquad\|\|\|\| \\
\text { 3' UACGGGAAAGUAGUAACGUGAC }\end{array}$ & in vitro & [91] \\
\hline
\end{tabular}


Table 1. Cont

\begin{tabular}{|c|c|c|c|c|c|c|c|}
\hline miRNA & $\begin{array}{c}\text { Disorder/Biological } \\
\text { Process }\end{array}$ & miR Level & $\begin{array}{l}\text { DKK1 Relative } \\
\text { Expression }\end{array}$ & \multicolumn{2}{|c|}{ miR Predicted Binding Site in 3'UTR of DKK1 } & \multirow{2}{*}{$\begin{array}{c}\text { Study Type } \\
\text { ex vivo }\end{array}$} & \multirow{2}{*}{$\begin{array}{r}\text { Ref } \\
{[92]}\end{array}$} \\
\hline miR-146a & Ankylosing spondylitis & $\uparrow$ & $\downarrow$ & $\begin{array}{l}\text { DKK1 3' UTR } \\
\text { miR-146a }\end{array}$ & $\begin{array}{l}5^{\prime}, \ldots \text { AUAUGUUUAAAGAUGAUCAGAGA... 3' } \\
\text { 3' GACUUCUUGACUUAAAGUCUCC }\end{array}$ & & \\
\hline $\operatorname{miR}-152$ & Multiple myeloma & $\downarrow$ & $\uparrow$ & $\begin{array}{l}\text { DKK1 3' UTR } \\
\text { miR-152 }\end{array}$ & $\begin{array}{l}5^{\prime} \text {....UUUCUAAAGGUGCUGCACUGC... 3' } \\
\text { 3' }|\|\mid\|\|\| \|\end{array}$ & $\begin{array}{l}\text { in vitro } \\
\text { in vivo }\end{array}$ & [93] \\
\hline${ }^{*} \mathrm{miR}-186-5 p$ & $\begin{array}{l}\text { Idiopathic pulmonary } \\
\text { fibrosis }\end{array}$ & $\downarrow$ & $\uparrow$ & $\begin{array}{l}\text { DKK1 3' UTR } \\
\text { miR-186-5p }\end{array}$ & 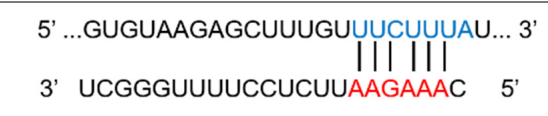 & $\begin{array}{l}\text { in vitro, } \\
\text { ex vivo, } \\
\text { in vivo }\end{array}$ & [94] \\
\hline \multirow{2}{*}{ miR-203 } & Lung adenocarcinoma & \multirow{2}{*}{$\downarrow$} & $\uparrow$ & $\begin{array}{l}\text { DKK1 3' UTR } \\
\text { miR-203 }\end{array}$ & $\begin{array}{l}5^{\prime} \text {....UGAACUGAAGUAAAUCAUUUCAG... 3' } \\
\text { || || || ||| || } \\
\text { 3' GAUCACCAGGAUUU-GUAAAGUG }\end{array}$ & $\begin{array}{l}\text { ex vivo, } \\
\text { in vitro }\end{array}$ & [95] \\
\hline & Osteoporosis & & $\uparrow$ & $\begin{array}{l}\text { DKK1 3' UTR } \\
\text { miR-203 }\end{array}$ & $\begin{array}{l}5^{\prime} \ldots \text {... UGAACUGAAGUAAAUCAUUUCAG... 3' } \\
\text { || } \text { 3' }^{\prime} \text { GAUCACCAGGAUUU-GUAAAGUG }\end{array}$ & in vitro & [96] \\
\hline \multirow{3}{*}{ miR-217 } & Colon cancer & $\uparrow$ & $\downarrow$ & $\begin{array}{l}\text { DKK1 3' UTR } \\
\text { miR-217 }\end{array}$ & $\begin{array}{l}\text { 5'...GAACUCCCCUGUGAUUGCAGUAA... 3' } \\
\text { 3' AGGUUAGUCAAGGACUACGUCAU 5' }\end{array}$ & in vitro & [97] \\
\hline & Hepatocellular carcinoma & $\uparrow$ & $\downarrow$ & $\begin{array}{l}\text { DKK1 3' UTR } \\
\text { miR-217 } \\
\text { DKK1 3' UTR } \\
\text { miR-217 }\end{array}$ & 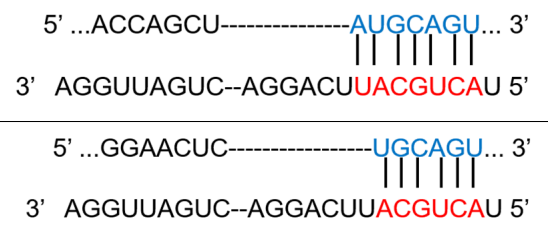 & $\begin{array}{c}\text { in vitro/ex vivo } \\
\text { in vivo }\end{array}$ & [98] \\
\hline & Osteonecrosis & $\downarrow$ & $\uparrow$ & $\begin{array}{l}\text { DKK1 3' UTR } \\
\text { miR-217 }\end{array}$ & $\begin{array}{l}\text { 5' ...GAACUCCCCUGUGAUUGCAGUAA... 3' } \\
\text { 3' AGGUUAGUCAAGGACUACGUCAU 5' }\end{array}$ & $\begin{array}{l}\text { in vitro, } \\
\text { ex vivo }\end{array}$ & [99] \\
\hline miR-291a-3p & Osteoporosis & $\downarrow$ & $\uparrow$ & $\begin{array}{l}\text { DKK1 3' UTR } \\
\text { miR-291a-3p }\end{array}$ & $\begin{array}{l}5^{\prime} \text {...UAAAUCCUCAGUGUG-GCACUUAC... 3' } \\
\text { 3' } \mid\|\|\|\| \\
\text { 3' CCGUGUGUUUCACCUU-CGUGAAA } 5^{\prime}\end{array}$ & $\begin{array}{l}\text { in vitro, } \\
\text { in vivo }\end{array}$ & {$[100]$} \\
\hline
\end{tabular}


Table 1. Cont

\begin{tabular}{|c|c|c|c|c|c|c|c|}
\hline miRNA & $\begin{array}{c}\text { Disorder/Biological } \\
\text { Process }\end{array}$ & miR Level & $\begin{array}{l}\text { DKK1 Relative } \\
\text { Expression }\end{array}$ & $\operatorname{miR} P_{1}$ & Binding Site in $3^{\prime} \mathrm{UTR}$ of DKK1 & Study Type & Ref. \\
\hline miR-302b-3p & Multiple myeloma & $\downarrow$ & $\uparrow$ & $\begin{array}{l}\text { DKK1 3' UTR } \\
\text { miR-302b-3p }\end{array}$ & $\begin{array}{l}\text { 5'...UAAAUUCUCAGUGUGGCACUUAC... 3' } \\
\text { 3' GAUGAUUUUGUACCUUCGUGAAU 5' }\end{array}$ & $\begin{array}{l}\text { in vitro, } \\
\text { in vivo }\end{array}$ & {$[101]$} \\
\hline \multirow{2}{*}{ miR-302e } & Cardiac hypertrophy & $\uparrow$ & $\mathrm{N} / \mathrm{A}$ & $\begin{array}{l}\text { DKK1 3' UTR } \\
\text { miR-302e }\end{array}$ & $\begin{array}{l}5^{\prime} \ldots \text {...AAAUUCUCAGUGUGGCACUUAC... } 3^{\prime} \\
3^{\prime} \quad \text { UUCGUACCUUCGUGAAU }\end{array}$ & in vitro & {$[102]$} \\
\hline & Cervical cancer & $\downarrow$ & $\uparrow$ & $\begin{array}{l}\text { DKK1 3' UTR } \\
\text { miR-302e }\end{array}$ & $\begin{array}{l}\text { 5'...UCUCAGUGUGGCACUUA... 3' } \\
\text { 3' UUCGUACCUUCGUGAAU 5' }\end{array}$ & $\begin{array}{l}\text { in vitro, } \\
\text { in vivo }\end{array}$ & {$[103]$} \\
\hline miR-335-5p & Diabetic osteoporosis & $\downarrow$ & $\uparrow$ & $\begin{array}{l}\text { DKK1 3' UTR } \\
\text { miR-335-5p }\end{array}$ & 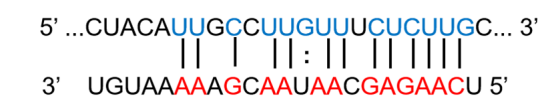 & in vitro & {$[104]$} \\
\hline miR-371/372/373 & Stem cell tumorigenesis & $\uparrow$ & $\downarrow$ & $\begin{array}{l}\text { DKK1 3' UTR } \\
\text { miR-371/312/373 }\end{array}$ & 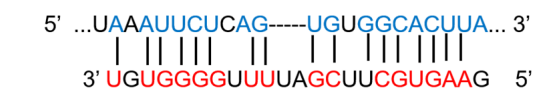 & in vitro & {$[105]$} \\
\hline miR-373-3p & $\begin{array}{l}\text { Tongue squamous cell } \\
\text { carcinoma }\end{array}$ & $\uparrow$ & $\downarrow$ & $\begin{array}{l}\text { DKK1 3' UTR } \\
\text { miR-373-3p }\end{array}$ & $\begin{array}{l}\text { 5' ...UAAAUUCUCAGUGUGGCACUUA... 3' } \\
\text { 3' } \text { " GUGGGGUUUUAGCUUCGUGAAG 5' }\end{array}$ & in vitro & {$[106]$} \\
\hline $\operatorname{miR}-410$ & Colorectal cancer & $\uparrow$ & $\downarrow$ & $\begin{array}{l}\text { DKK1 3' UTR } \\
\text { miR-410 }\end{array}$ & $\begin{array}{l}5^{\prime}, \ldots \text { GCAGUGAACUCCUUUUAUAUA... 3' } \\
\text { 3' }|\||\|| \mid \\
\text { 3' UGUCCGGUAGACACAAUAUAA 5' }\end{array}$ & in vitro & {$[107]$} \\
\hline miR-433-3p & Osteogenic differentiation & $\uparrow$ & $\downarrow$ & $\begin{array}{l}\text { DKK1 3' UTR } \\
\text { miR-433-3p }\end{array}$ & $\begin{array}{l}\text { 5' ...AUUUAACAUUUAAUAUCAUGAA... 3' } \\
:\|\|\|\| \||| \\
\text { 3' UGUGGCUCCUCGGGUAGUACUA 5' }\end{array}$ & in vitro & {$[108]$} \\
\hline $\operatorname{miR}-488$ & Fracture & $\downarrow$ & $\uparrow$ & $\begin{array}{l}\text { DKK1 3' UTR } \\
\text { miR-488 }\end{array}$ & $\begin{array}{l}\text { 5' ...AUCUUACAUUACUACUUUCAA... 3' } \\
\text { 3' CUGGUUCUUUAUCGGAAAGUU 5' }\end{array}$ & in vitro & {$[109]$} \\
\hline miR-493-3p & Gastric cancer & $\uparrow$ & $\downarrow$ & $\begin{array}{l}\text { DKK1 3' UTR } \\
\text { miR-493-3p }\end{array}$ & 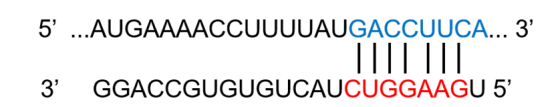 & in vitro & {$[110]$} \\
\hline
\end{tabular}


Table 1. Cont

\begin{tabular}{|c|c|c|c|c|c|c|c|}
\hline miRNA & $\begin{array}{c}\text { Disorder/Biological } \\
\text { Process }\end{array}$ & miR Level & $\begin{array}{l}\text { DKK1 Relative } \\
\text { Expression }\end{array}$ & $\mathrm{miR}$ & Predicted Binding Site in $3^{\prime}$ UTR of DKK1 & Study Type & Ref. \\
\hline $\operatorname{miR}-522$ & Hepatocellular carcinoma & $\uparrow$ & $\downarrow$ & $\begin{array}{l}\text { DKK1 3' UTR } \\
\text { miR-522 }\end{array}$ & $\begin{array}{c}5^{\prime}, \ldots \text {...CAUAACCCUUUACCCCAUUUAA... 3' } \\
\text { 3' } \quad \text { UGUGAGAUUUCCCUUGGUAAAA 5' }\end{array}$ & in vitro & {$[111]$} \\
\hline miR-523-3p & Retinoblastoma & $\uparrow$ & $\downarrow$ & $\begin{array}{l}\text { DKK1 3' UTR } \\
\text { miR-523-3p }\end{array}$ & $\begin{array}{l}\text { 5'...GACUUAUGAACUAUUCUAGAG... 3' } \\
\text { 3' AgCUUAUGCGAUUAAGAUCUA 5' }\end{array}$ & $\begin{array}{l}\text { in vitro, } \\
\text { ex vivo }\end{array}$ & [112] \\
\hline miR-613 & Rheumatoid arthritis & $\downarrow$ & $\uparrow$ & $\begin{array}{l}\text { DKK1 3' UTR } \\
\text { miR-613 }\end{array}$ & 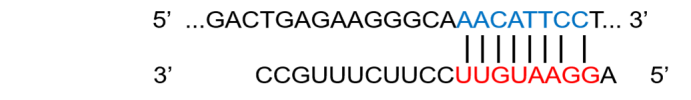 & in vitro & [113] \\
\hline miR-3064-3p & $\begin{array}{l}\text { Cementoblast } \\
\text { differentiation }\end{array}$ & $\downarrow$ & $\uparrow$ & $\begin{array}{l}\text { DKK1 3' UTR } \\
\text { miR-3064-3p }\end{array}$ & $\begin{array}{l}\text { 5' ...TGTTGTAAATCCTCAGTGTGGCA... 3' } \\
\qquad|\|||||||| \\
\text { 3' } \quad \text { ACAUUCCACAACGUCACACCGU }\end{array}$ & in vitro & [114] \\
\hline miR-6783-3p & Lung adenocarcinoma & $\uparrow$ & $\downarrow$ & $\begin{array}{l}\text { DKK1 3' UTR } \\
\text { miR-6783-3p }\end{array}$ & 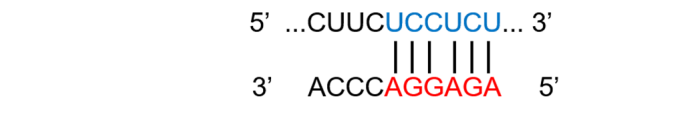 & $\begin{array}{l}\text { in vitro, } \\
\text { in vivo }\end{array}$ & [115] \\
\hline miR-6807-3p & Lung adenocarcinoma & $\uparrow$ & $\downarrow$ & $\begin{array}{l}\text { DKK1 3' UTR } \\
\text { miR-6807-3p }\end{array}$ & $\begin{array}{l}\text { 5' ...GAACUCCCCUGUGAUUGCAGUAA... 3' } \\
\text { 3' GACCCGGUUCGUCCUUACGUCAC } 5 \text {, }\end{array}$ & $\begin{array}{l}\text { in vitro, } \\
\text { in vivo }\end{array}$ & [116] \\
\hline miR-BART10-3p & Gastric carcinoma & $\uparrow$ & $\downarrow$ & $\begin{array}{l}\text { DKK1 3' UTR } \\
\text { miR-BART10-3p }\end{array}$ & 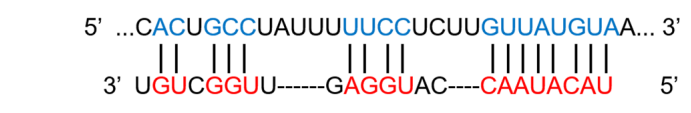 & in vitro & [117] \\
\hline miR-BART22 & Gastric carcinoma & $\uparrow$ & $\downarrow$ & $\begin{array}{l}\text { DKK1 3' UTR } \\
\text { miR-BART22 }\end{array}$ & 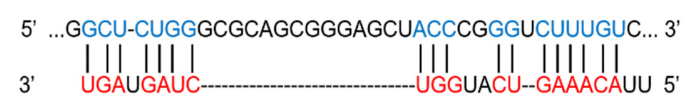 & in vitro & {$[118]$} \\
\hline
\end{tabular}

Notes: Dots between miRNA and DKK1 sequence indicate wobble pairing. N/A, not applicable. *, These binding sites are cited from TargetScan.org. 


\section{Available and Recently Studied Therapeutics for AGA}

Up until now, there are no clinical trials regarding miRNA therapy for hair growth. To develop the miRNA-based drug for AGA treatment, the appropriate miRNA candidates should be carefully selected, which is the main purpose of this manuscript. Before getting straight to that point, other available approaches are also discussed. Notably, there was no commercially available mRNA-based vaccine before the COVID-19 outbreak. However, effective mRNA vaccines that are being widely used nowadays are hailed as a milestone in vaccinology. Similarly, miRNA-based drugs may become another breakthrough in drug development in the near future. Moreover, some miRNAs are already in clinical trials [65].

Among the currently accessible methods of AGA treatment, transplantation is considered to be the conventional technique, e.g., platelet-rich plasma therapy, follicular unit extraction, and strip harvesting. However, the effectiveness still needs to be studied properly [119]. In several topical and oral medications, minoxidil has already been widely used as a hair loss remedy. Although the exact mechanism of its action is still elusive $[120,121]$, it is evidenced that minoxidil increases the levels of factors that play major roles in hair growth [51], e.g., Wnt5 $\alpha$ and vascular endothelial growth factor (VEGF) [122], $\beta$-catenin activity, and expression in DP cells [123], while its action results in the downregulation of DKK1 in HDPCs [51]. According to Choi et al., minoxidil promotes the hair growth and proliferation of DP cells via stimulating the release of growth factor from adipose-derived stem cells [124]. Despite its broad application and effects, this medication still exhibits some side effects [121]. Another orally and topically available agent finasteride reduces DHT levels, but has adverse sexual side effects $[125,126]$. Similar side effects are displayed when oral dutasteride is applied [125,127]. Finasteride [128] and dutasteride [129,130] inhibit $5 \alpha R$, and thus hinder the production of DHT from testosterone [131]. Despite the side effects, topical minoxidil and oral finasteride are already approved by the FDA and remain the key therapeutics up until now [132]. Low-level laser therapy (LLLT) also seems to improve hair regrowth in the conditions of AGA, AA, and chemotherapy-induced alopecia [133]. There are studies demonstrating the positive effects of natural bioactive compounds on AGA $[24,30,52,55,56,58,134-138]$. A recently published study demonstrates that a 5-mer peptide (GLYYF; P5) has the potential to promote hair growth when topically applied [139]. Remarkably, stem-cell-based therapy for AGA is also being researched [140]. Aiming to renew the damaged HFs via replacing them with in vitro reconstructed HFs seems promising. Nevertheless, certain issues hamper this approach to be developed [141]. Cholesterol-modified siRNA has also been evidenced to be worthy for topical application for alopecia treatment [142]. Interestingly, the exosomes-membrane-bound extracellular vesicles that are functionally pleiotropic nanoparticles-have also demonstrated their positive role on hair growth in cultured HF $[77,140,143]$. Exosomes carry exosomal cargos that contain various miRNAs together with other nucleic acids, proteins, lipids, etc. [144]. Thus, although it may be considered as a future approach, the strategy of exosome application for hair growth needs to be carefully developed as the interplay of exosomal miRNAs and other molecules is very complex.

\section{6. miRNA Involvement in Hair Growth Regulation}

miRNAs are already evidenced to play a substantial role in HF development. The functions of miRNAs are very diverse. The same miRNA has the ability to regulate multiple gene expression. Except for hair growth, miRNAs are related to having a strong influence on osteogenesis, the wound-healing process, tumorigenesis, etc. miRNAs are considered strong gene regulators as they control gene expression. Primary miRNA (pri-miRNA) - the initial form of these small non-coding RNA molecule-is transcribed from introns, then cleaved by an enzyme, Drosha [145]. As a result, a precursor miRNA (pre-miRNA) is formed, which is translocated from the nucleus into the cytoplasm by an exportin-5. In the cytoplasm, it is further processed, the terminal loop is removed by the enzyme Dicer, and mature miRNA duplex formation takes place. It is then recognized by the Argonaute (AGO) protein family that is the part of the RNA-induced silencing complex (RISC), and 
the guide strand of miRNA is loaded into RISC while the passenger strand is unloaded and degraded [146]. The remaining 22 nucleotide-length miRNA is capable to bind the target region of specific mRNA on the $3^{\prime}$ untranslated region ( $3^{\prime}$ UTR) and induces silencing via deadenylation and decapping and, as a result, post-transcriptional regulation of gene expression occurs [147]. The seed region-about 2-8 nucleotides of the $5^{\prime}$ end-determines the specificity of the miRNA guide strand to the $3^{\prime}$ UTR of target mRNA [148]. However, the miRNA-target interaction is not conserved between certain species [148].

Since the first identification of miRNAs in the human body, the link between miRNAs and hair growth regulation was also soon discovered [149]. However, as yet, there is no ideal miRNA-based strategy for hair regrowth developed as the mechanisms are not fully understood. During the hair growth cycle, the expression of miRNAs varies according to the hair growth phases $[150,151]$. miRNAs are implicated in the development of skin appendages [73]. Hence, these small nucleic acid molecules seem to be a great therapeutic target for the treatment of AGA.

According to the abovementioned description, hair growth is a complex process that consists of three main phases. Normally, in the telogen phase, hair falls from the scalp and a new anagen starts to induce a new hair growth cycle. In patients with AGA, the transition from the telogen to anagen phase is hindered. The shifting process is controlled by various signaling pathways that can induce or delay transition between phases [152]. miRNAs that play one of the key roles in the hair cycle sensibly merit the attention in molecular biology studies. The possible impact of certain miRNAs on telogen to anagen transition via regulating Wnt/ $\beta$-catenin signaling pathway is illustrated in Figure 4.

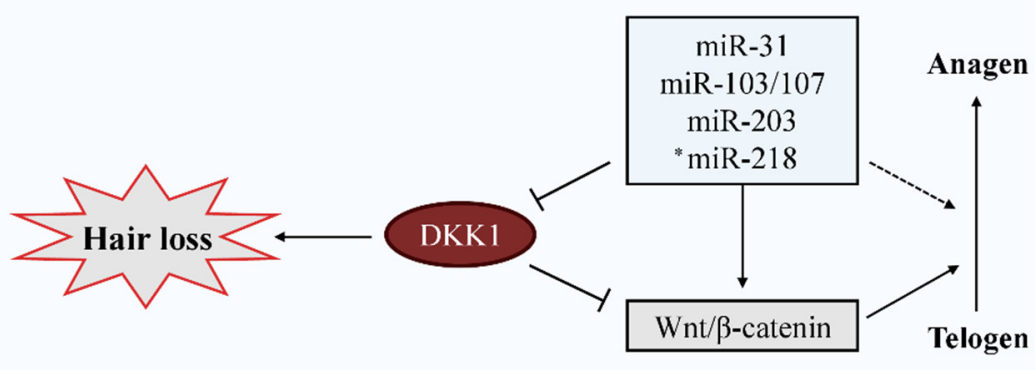

Figure 4. Illustration of potential implication of miRNAs on telogen to anagen transition. miR-31, miR-103/107, miR-203, and miR-218 regulate DKK1 levels and activate the Wnt/ $\beta$-catenin signaling pathway, which influences telogen to anagen transition. Abbreviations: DKK1, dickkopf-related protein 1. * Indirect inhibition of DKK1 [153].

Although their principal function in the body is already evidenced, there are still aspects that need to be elucidated. There are a number of miRNAs that play certain roles in different stages of HF development [73]. Indeed, studies have demonstrated that miR$218-5 p$ promotes hair regeneration in mice via targeting SFRP2 [76,77]. However, in these studies, DKK1 levels were not observed. Basically, the Wnt/ $\beta$-catenin signaling pathway is a common pathway for different pathophysiological processes, e.g., cancer, where certain miRNAs influence Wnt/ $\beta$-catenin through inhibiting DKK1 and other involved proteins. Here, we discuss miRNAs that might be implicated in the development of hair growth and that may have a significant outcome in designing miRNA-based sustainable therapy. It is critical to identify the key miRNAs that are essential in hair regrowth to treat AGA.

Interestingly, miR-125 is abundantly expressed in balding DP cells [151]. Moreover, it is found to inhibit the receptor of vitamin $D$, which is required for hair growth [154] as it activates Wnt/ $\beta$-catenin signaling, among other pathways in keratinocytes [155]. Hence, the inhibition of the vitamin $D$ receptor results in the impairment of hair growth [154]. miR126 is evidenced to be present in HFs [156], which stipulates that it might be implicated 
in hair growth regulation. However, there are insufficient studies regarding miR-126. Interestingly, the miR-133b level was abnormally increased in patients with AGA and the levels of $\beta$-catenin in HDPCs were decreased, indicating its negative influence on hair growth [150]. The potential influence of key miRNAs in the hair growth process via modulating the Wnt/ $\beta$-catenin signaling pathway is presented in Figure 5. In addition, Deng et al. have demonstrated that the expression of some miRNAs (miR-133b, miR-141$5 p$, miR-652-5p, miR-520d-5p, and miR-1247-5p) was markedly upregulated, while the expression of other miRNAs (miR-378d, miR-4286, and miR-3607-5p) was downregulated in the affected region of the AGA group. On the other hand, the expression of miR-133b, miR-141-5p, miR-652-5p, and miR-1247-5p was highly elevated in the affected region of AGA compared with the non-affected region of AGA patients [150]. Broad information of critical miRNAs that may be useful for designing studies on hair morphogenesis is combined in Table 2.

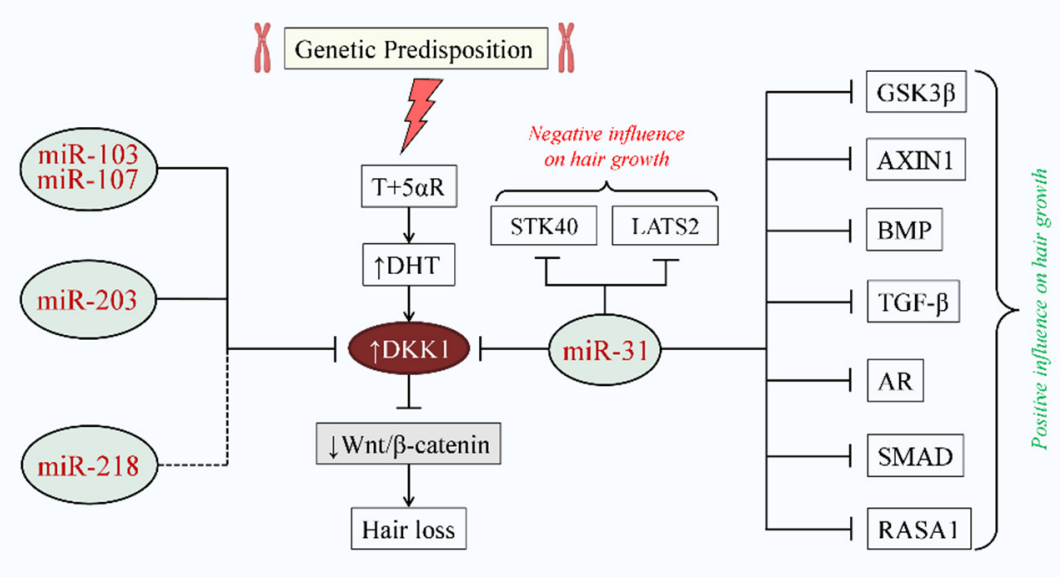

Figure 5. Potential implication of DKK1-targeting key miRNAs in genetically predisposed hair loss. In a genetically predisposed population, $\mathrm{T}$ is converted to DHT by $5 \alpha \mathrm{R}$. Upregulated DHT induces DKK1 expression. DKK1 inhibits Wnt/ $\beta$-catenin signaling and hair loss takes place. miR103/107, miR-203, and miR-218 reduce the DKK1 level, which might prevent hair growth, while miR-31 potentially inhibits DKK1 and other proteins that might also modulate the hair growth cycle. Abbreviations: T, testosterone; DHT, dihydrotestosterone; $5 \alpha \mathrm{R}, 5$ alpha-reductase; DKK1, dickkopf-related protein 1 ; GSK-3 $\beta$, glycogen synthase kinase $3 \beta$; STK40, serine/threonine kinase 40; LATS2, large tumor-suppressor kinase 2; BMP, bone morphogenetic protein; TGF- $\beta$, transforming growth factor- $\beta$; AR, androgen receptor; RASA1, RAS p 21 protein activator 1 . Dashed line indicates the indirect inhibition of DKK1. 


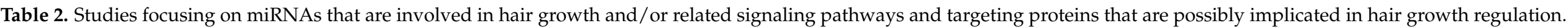

\begin{tabular}{|c|c|c|c|c|c|c|c|c|c|}
\hline \# & Study Title & miRNA & $\begin{array}{l}\text { Influence on Hair } \\
\text { Growth }\end{array}$ & Study Model & $\begin{array}{c}\text { Type of } \\
\text { Administration }\end{array}$ & Biological Function & Target Protein/Gene & Finding & Ref. \\
\hline 1 & $\begin{array}{l}\text { Differential expression of } \\
\text { miR-let7a in hair follicle cycle of } \\
\text { Liaoning cashmere goats and } \\
\text { identification of its targets }\end{array}$ & miR-let7a & Regulatory & $\begin{array}{l}\text { Goat skin samples, } \\
\text { cell culture }\end{array}$ & in vitro transfection & $\begin{array}{l}\text { Regulating FGF, IGF, } \\
\text { C-Myc signaling } \\
\text { pathways }\end{array}$ & $\begin{array}{l}\text { IGF-1R, C-Myc, } \\
\text { FGF5 }\end{array}$ & $\begin{array}{c}\text { miR-let7a regulates HF } \\
\text { development via targeting } \\
\text { C-myc, IGF-1R, and FGF5 }\end{array}$ & [157] \\
\hline 2 & $\begin{array}{l}\text { Let- } 7 \mathrm{~b} \text { regulates alpaca hair } \\
\text { growth by downregulating } \\
\text { ectodysplasin A }\end{array}$ & miR-let-7b & Regulatory & $\begin{array}{l}\text { Alpaca, } \\
\text { cell culture }\end{array}$ & in vitro transfection & Inhibiting EDA signaling & EDA & $\begin{array}{l}\text { miR-let-7b regulates hair } \\
\text { growth via targeting EDA }\end{array}$ & [158] \\
\hline 3 & $\begin{array}{l}\text { Identification of microRNA-21 } \\
\text { target genes associated with hair } \\
\text { follicle development in sheep }\end{array}$ & miR-21 & Regulatory & Sheep & in vitro transfection & $\begin{array}{c}\text { Regulating } \\
\text { CNKSR2-MAPK, KLF3, } \\
\text { TNPO1-CCR2 signaling } \\
\text { pathways } \\
\end{array}$ & $\begin{array}{l}\text { CNKSR2, KLF3, } \\
\text { TNPO1 }\end{array}$ & $\begin{array}{l}\text { miR-21 targets CNKSR2, } \\
\text { KLF3, and TNPO1 that might } \\
\text { play a regulatory role in HF } \\
\text { development }\end{array}$ & [159] \\
\hline 4 & $\begin{array}{l}\text { EZH2-mediated inhibition of } \\
\text { microRNA-22 promotes } \\
\text { differentiation of hair follicle stem } \\
\text { cells by elevating STK40 } \\
\text { expression }\end{array}$ & $\mathrm{miR}-22$ & Negative & $\begin{array}{c}\text { Mouse, } \\
\text { cell culture }\end{array}$ & in vitro transfection & $\begin{array}{l}\text { Inhibiting MEF2-ALP } \\
\text { signaling }\end{array}$ & STK40 & $\begin{array}{l}\text { miR-22 targets STK40 and } \\
\text { inhibits the MEF2-ALP } \\
\text { signaling pathway, and thus } \\
\text { impedes the proliferation and } \\
\text { differentiation of HFSC }\end{array}$ & [160] \\
\hline 5 & $\begin{array}{l}\text { Post-transcriptional regulation of } \\
\text { keratinocyte progenitor cell } \\
\text { expansion, differentiation and hair } \\
\text { follicle regression by miR-22 }\end{array}$ & & Negative & $\begin{array}{l}\text { Mouse, } \\
\text { cell culture }\end{array}$ & in vitro transfection & $\begin{array}{l}\text { Activating apoptotic } \\
\text { signaling pathways }\end{array}$ & $\begin{array}{l}\text { DLX3, FOXN1, } \\
\text { HOXC13 }\end{array}$ & $\begin{array}{l}\text { miR-22 is a critical } \\
\text { post-transcriptional regulator } \\
\text { of the hair cycle and its } \\
\text { activation results in hair loss }\end{array}$ & [161] \\
\hline 6 & $\begin{array}{l}\text { miR-24 affects hair follicle } \\
\text { morphogenesis targeting Tcf-3 }\end{array}$ & $\mathrm{miR}-24$ & Negative & $\begin{array}{l}\text { Mouse, } \\
\text { cell culture }\end{array}$ & in vitro transfection & $\begin{array}{c}\text { Regulating } \\
\text { Wnt } / \beta \text {-catenin signaling }\end{array}$ & TCF-3 & $\begin{array}{l}\text { miR-24 is expressed in the HF } \\
\text { and it directly targets TCF-3, a } \\
\text { regulator of the hair } \\
\text { keratinocyte stemness }\end{array}$ & [162] \\
\hline 7 & $\begin{array}{l}\text { miR-24 controls the regenerative } \\
\text { competence of hair follicle } \\
\text { progenitors by targeting Plk3 }\end{array}$ & & Negative & $\begin{array}{l}\text { Mouse, } \\
\text { cell culture }\end{array}$ & in vitro transfection & $\begin{array}{l}\text { Regulating PLK3-CCNE1 } \\
\text { signaling }\end{array}$ & PLK3 & $\begin{array}{l}\text { miR-24 by targeting PLK3 } \\
\text { limits the intrinsic growth } \\
\text { competence of HF progenitor }\end{array}$ & [163] \\
\hline 8 & $\begin{array}{l}\text { miR-29 modulates Wnt signaling } \\
\text { in human osteoblasts through a } \\
\text { positive feedback loop }\end{array}$ & miR-29a & N/A & Cell culture & in vitro transfection & $\begin{array}{c}\text { Activating } \\
\text { Wnt } / \beta \text {-catenin signaling }\end{array}$ & $\begin{array}{l}\text { DKK1, SFRP2, } \\
\text { KRM2 }\end{array}$ & $\begin{array}{l}\text { miR-29a potentiates Wnt } \\
\text { signaling via downregulation } \\
\text { of the key antagonists of Wnt } \\
\text { signaling, DKK1, KRM2, and } \\
\text { SFRP2, which contributes to a } \\
\text { gene expression program } \\
\text { important for osteoblast } \\
\text { differentiation }\end{array}$ & [164] \\
\hline 9 & $\begin{array}{c}\text { miR-29 suppression of osteonectin } \\
\text { in osteoblasts: regulation during } \\
\text { differentiation and by canonical } \\
\text { Wnt signaling }\end{array}$ & & $\mathrm{N} / \mathrm{A}$ & Cell culture & in vitro transfection & $\begin{array}{c}\text { Activating } \\
\text { Wnt } \beta \text {-catenin signaling }\end{array}$ & DKK1 & $\begin{array}{l}\text { miR-29a and Wnt signaling } \\
\text { antagonist DKK1 expressions } \\
\text { are negatively correlated }\end{array}$ & [165] \\
\hline
\end{tabular}


Table 2. Cont

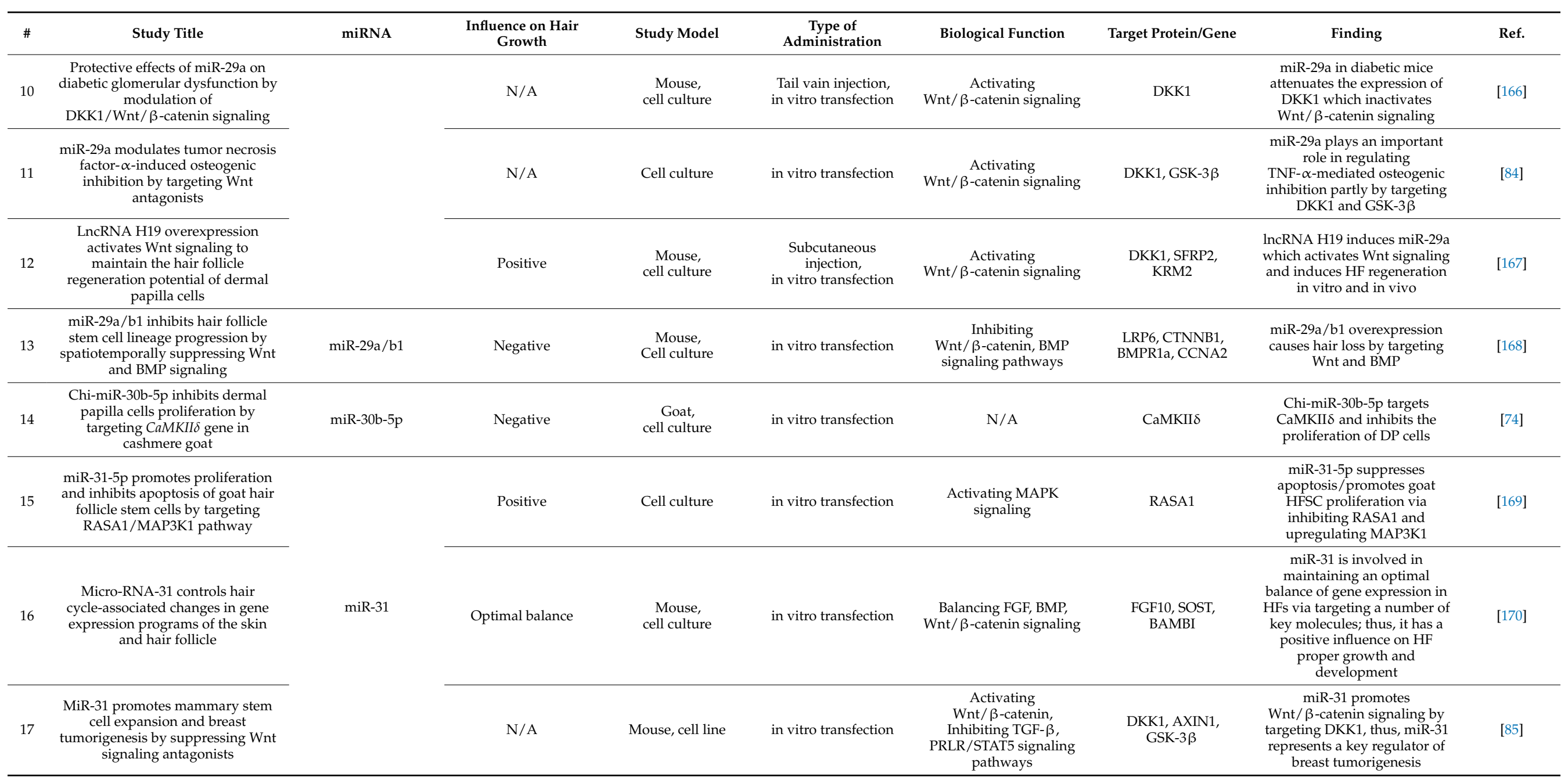


Table 2. Cont

\begin{tabular}{|c|c|c|c|c|c|c|c|c|c|}
\hline$\#$ & Study Title & miRNA & $\begin{array}{c}\text { Influence on Hair } \\
\text { Growth }\end{array}$ & Study Model & $\begin{array}{c}\text { Type of } \\
\text { Administration }\end{array}$ & Biological Function & Target Protein/Gene & Finding & Ref. \\
\hline 18 & $\begin{array}{c}\text { Down-regulation of } \\
\text { microRNA-31-5p inhibits } \\
\text { proliferation and invasion of } \\
\text { osteosarcoma cells through } \\
\text { Wnt/ } \beta \text {-catenin signaling pathway } \\
\text { by enhancing AXIN1 }\end{array}$ & & $\mathrm{N} / \mathrm{A}$ & $\begin{array}{l}\text { Tumor samples cell } \\
\text { culture }\end{array}$ & in vitro transfection & $\begin{array}{c}\text { Activating } \\
\text { Wnt } \beta \text {-catenin signaling }\end{array}$ & AXIN1 & $\begin{array}{l}\text { miR-31-5p targets AXIN1, and } \\
\text { via inhibiting the } \\
\text { transcription of AXIN1, it } \\
\text { activates Wnt/ } \beta \text {-catenin } \\
\text { signaling in OS cells }\end{array}$ & [171] \\
\hline 19 & $\begin{array}{l}\text { The major miR-31 target genes } \\
\text { STK40 and LATS2 and their } \\
\text { implications in the regulation of } \\
\text { keratinocyte growth and hair } \\
\text { differentiation }\end{array}$ & & Negative & $\begin{array}{l}\text { Mouse, } \\
\text { cell culture }\end{array}$ & in vitro transfection & $\begin{array}{l}\text { Promoting aberrant } \\
\text { keratinocyte growth }\end{array}$ & STK40, LATS2 & $\begin{array}{l}\text { miR-31 targets a large number } \\
\text { of gene expressions, including } \\
\text { STK40 and LATS2, that play a } \\
\text { role in keratinocyte growth } \\
\text { and HF biology }\end{array}$ & [172] \\
\hline 20 & $\begin{array}{l}\text { Downregulation of LINC00707 } \\
\text { promotes osteogenic } \\
\text { differentiation of human bone } \\
\text { marrow-derived mesenchymal } \\
\text { stem cells by regulating DKK1 via } \\
\text { targeting miR-103a-3p }\end{array}$ & miR-103a-3p & $\mathrm{N} / \mathrm{A}$ & Cell culture & in vitro transfection & $\begin{array}{c}\text { Activating } \\
\text { Wnt } \beta \text {-catenin signaling }\end{array}$ & DKK1 & $\begin{array}{l}\text { LINC00707 regulates the } \\
\text { expression of DKK1 by } \\
\text { targeting miR-103a-3p }\end{array}$ & [89] \\
\hline 21 & $\begin{array}{l}\text { MicroRNAs-103/107 regulate } \\
\text { autophagy in the epidermis }\end{array}$ & miR-103/107 & Positive & $\begin{array}{l}\text { Mouse, } \\
\text { cell culture }\end{array}$ & $\begin{array}{l}\text { Subcutaneous } \\
\text { injection }\end{array}$ & Activating PKC signaling & PLD1, PLD2 & $\begin{array}{l}\text { miR-103/107 may play an } \\
\text { important role in maintaining } \\
\text { the stemness of HFSCs and its } \\
\text { levels may decrease with age }\end{array}$ & [173] \\
\hline 22 & $\begin{array}{c}\text { In vitro effect of microRNA-107 } \\
\text { targeting Dkk-1 by regulation of } \\
\text { Wnt } / \beta \text {-catenin signaling pathway } \\
\text { in osteosarcoma }\end{array}$ & miR-107 & $\mathrm{N} / \mathrm{A}$ & $\begin{array}{l}\text { OS tissue, } \\
\text { cell culture }\end{array}$ & in vitro transfection & $\begin{array}{c}\text { Activating } \\
\text { Wnt } \beta \text {-catenin signaling }\end{array}$ & DKK1 & $\begin{array}{c}\text { miR-107 inhibits the } \\
\text { occurrence and development } \\
\text { of OS by downregulating } \\
\text { DKK1 through the } \\
\text { Wnt/ } \beta \text {-catenin signaling } \\
\text { pathway }\end{array}$ & [90] \\
\hline 23 & $\begin{array}{c}\text { miR-124 promotes neural } \\
\text { differentiation in mouse bulge } \\
\text { stem cells by repressing Ptbp1 and } \\
\text { Sox9 }\end{array}$ & miR-124 & Positive & $\begin{array}{l}\text { Mouse, } \\
\text { cell culture }\end{array}$ & in vitro transfection & $\begin{array}{l}\text { Promoting HFSCs } \\
\text { neuronal differentiation }\end{array}$ & SOX9, PTBP1 & $\begin{array}{l}\text { miR-124 promotes HFSCs } \\
\text { neuronal differentiation via } \\
\text { targeting SOX9 and PTBP1 }\end{array}$ & [174] \\
\hline 24 & $\begin{array}{l}\text { miR-125/CDK2 axis in cochlear } \\
\text { progenitor cell proliferation }\end{array}$ & miR-125 & Negative & $\begin{array}{l}\text { Rat, } \\
\text { cell culture }\end{array}$ & in vitro transfection & Inhibiting CDK pathway & CDK2 & $\begin{array}{l}\text { miR- } 125 \text { inhibits the } \\
\text { proliferation of CPC by } \\
\text { downregulating CDK2 }\end{array}$ & [175] \\
\hline 25 & $\begin{array}{l}\text { Chi-miR-130b-3p regulates Inner } \\
\text { Mongolia cashmere goat skin hair } \\
\text { follicles in fetuses by targeting } \\
\text { Wnt family member 10A }\end{array}$ & miR-130b-3p & Negative & Cell culture & in vitro transfection & $\begin{array}{c}\text { Inhibiting } \\
\text { Wnt/ } \beta \text {-catenin signaling }\end{array}$ & Wnt10a & $\begin{array}{l}\text { The study suggests that } \\
\text { Wnt10a is a target gene of } \\
\text { chi-miR-130b-3p. Thus, } \\
\text { chi-miR-130b-3p may regulate } \\
\text { epithelial cell and dermal } \\
\text { fibroblast proliferation }\end{array}$ & [176] \\
\hline
\end{tabular}


Table 2. Cont

\begin{tabular}{|c|c|c|c|c|c|c|c|c|c|}
\hline \# & Study Title & miRNA & $\begin{array}{c}\text { Influence on Hair } \\
\text { Growth }\end{array}$ & Study Model & $\begin{array}{c}\text { Type of } \\
\text { Administration }\end{array}$ & Biological Function & Target Protein/Gene & Finding & Ref. \\
\hline 26 & $\begin{array}{l}\text { Expression profiling and } \\
\text { functional characterization of } \\
\text { miR-26a and miR-130a in } \\
\text { regulating Zhongwei goat hair } \\
\text { development via the TGF- } \beta \\
\text { /SMAD pathway }\end{array}$ & $\begin{array}{l}\text { miR-130a } \\
\text { miR-26a }\end{array}$ & $\begin{array}{l}\text { Negative (miR-130a) } \\
\text { Positive (miR-26) }\end{array}$ & $\begin{array}{l}\text { Goat, } \\
\text { cell culture }\end{array}$ & in vitro transfection & $\begin{array}{c}\text { Regulating } \\
\text { TGF- } \beta \text { /SMAD pathway }\end{array}$ & SMAD5, SMAD1 & $\begin{array}{l}\text { miR-26a and miR-130a } \\
\text { regulate the HF development } \\
\text { and growth through } \\
\text { implication in TGF- } \\
\beta / \text { SMAD signaling pathway }\end{array}$ & [177] \\
\hline 27 & $\begin{array}{l}\text { miRNA microarray profiling in } \\
\text { patients with androgenic alopecia } \\
\text { and the effects of miR-133b on hair } \\
\text { growth }\end{array}$ & miR-133b & Negative & $\begin{array}{l}\text { AGA scalp, } \\
\text { cell culture }\end{array}$ & in vitro transfection & $\begin{array}{c}\text { Inhibiting } \\
\text { Wnt/ } \beta \text {-catenin signaling }\end{array}$ & $\begin{array}{l}\text { ALP, } \beta \text {-catenin, } \\
\text { versican }\end{array}$ & $\begin{array}{c}\text { miR-133b is abnormally } \\
\text { highly expressed in patients } \\
\text { with AGA. miR-133b may } \\
\text { inactivate the Wnt } \beta \text {-catenin } \\
\text { pathway, and thus regulate } \\
\text { hair growth }\end{array}$ & [150] \\
\hline 28 & $\begin{array}{l}\text { miR-140-5p in small extracellular } \\
\text { vesicles from human papilla cells } \\
\text { stimulates hair growth by } \\
\text { promoting proliferation of outer } \\
\text { root sheath and hair matrix cells }\end{array}$ & miR-140-5p & Positive & Cell culture & in vitro transfection & Inhibiting BMP signaling & BMP2 & $\begin{array}{l}\text { miR-140-5p plays a critical } \\
\text { role in hair growth and cell } \\
\text { proliferation and it represents } \\
\text { a therapeutic target for } \\
\text { alopecia }\end{array}$ & [178] \\
\hline 29 & $\begin{array}{l}\text { Preliminary study on microR-148a } \\
\text { and microR-10a in dermal papilla } \\
\text { cells of Hu sheep }\end{array}$ & miR-148amiR-10a & $\mathrm{N} / \mathrm{A}$ & Cell culture & in vitro transfection & $\begin{array}{c}\text { Inhibiting BMP signaling, } \\
\text { regulating } \\
\text { TGF- } \beta \text { /Smads signaling }\end{array}$ & BMP7 & $\begin{array}{c}\text { miR-148a and miR-10a } \\
\text { inhibits the proliferation of } \\
\text { Hu sheep dermal papilla cells }\end{array}$ & [179] \\
\hline 30 & $\begin{array}{l}\text { MicroRNA-148b promotes } \\
\text { proliferation of hair follicle cells by } \\
\text { targeting NFAT5 }\end{array}$ & miR-148b & Positive & Cell culture & in vitro transfection & $\begin{array}{c}\text { Activating } \\
\text { Wnt/ } \beta \text {-catenin signaling }\end{array}$ & NFAT5, Wnt10b & $\begin{array}{c}\text { miR-148b activates the } \\
\text { Wnt/ } \beta \text {-catenin signaling } \\
\text { pathway by targeting } N F A T 5 \\
\text { and promotes the } \\
\text { proliferation of human HF } \\
\text { cells }\end{array}$ & [180] \\
\hline 31 & $\begin{array}{l}\text { miR-149-5p regulates goat hair } \\
\text { follicle stem cell proliferation and } \\
\text { apoptosis by targeting the } \\
\text { CMTM3/AR axis during } \\
\text { superior-quality brush hair } \\
\text { formation }\end{array}$ & miR-149-5p & Positive & $\begin{array}{l}\text { Goat, } \\
\text { cell culture }\end{array}$ & in vitro transfection & $\begin{array}{c}\text { Regulating AR } \\
\text { transcriptional activity }\end{array}$ & СMTM3 & $\begin{array}{l}\text { miR-149-5p suppresses HF } \\
\text { stem cell apoptosis by } \\
\text { inhibiting CMTM3 and } \\
\text { regulates the high-quality hair } \\
\text { formation in goats }\end{array}$ & [181] \\
\hline 32 & $\begin{array}{l}\text { Downregulation of MicroRNA-152 } \\
\text { contributes to high expression of } \\
\text { DKK1 in multiple myeloma }\end{array}$ & miR-152 & $\mathrm{N} / \mathrm{A}$ & $\begin{array}{l}\text { Mouse, } \\
\text { cell culture }\end{array}$ & $\begin{array}{l}\text { Femur injection, } \\
\text { in vitro transfection }\end{array}$ & $\begin{array}{c}\text { Activating } \\
\text { Wnt } / \beta \text {-catenin signaling }\end{array}$ & DKK1 & $\begin{array}{l}\text { miR-152 blocked DKK1 } \\
\text { transcriptional activity by } \\
\text { binding to the } 3^{\prime} \text { UTR of DKK1 } \\
\text { mRNA. miR-152 is a master } \\
\text { regulator in the pathobiology } \\
\text { of MM via targeting DKK1 }\end{array}$ & [93] \\
\hline 33 & $\begin{array}{l}\text { The effect of the microRNA-183 } \\
\text { family on hair cell-specific markers } \\
\text { of human bone marrow-derived } \\
\text { mesenchymal stem cells }\end{array}$ & miR-182 & Positive & Cell culture & in vitro transfection & N/A & $\mathrm{N} / \mathrm{A}$ & $\begin{array}{l}\text { miR-182 plays a key role in } \\
\text { hair cell differentiation }\end{array}$ & [182] \\
\hline
\end{tabular}


Table 2. Cont

\begin{tabular}{|c|c|c|c|c|c|c|c|c|c|}
\hline \# & Study Title & miRNA & $\begin{array}{l}\text { Influence on Hair } \\
\text { Growth }\end{array}$ & Study Model & $\begin{array}{c}\text { Type of } \\
\text { Administration } \\
\end{array}$ & Biological Function & Target Protein/Gene & Finding & Ref. \\
\hline 34 & $\begin{array}{l}\text { microRNA-183 is involved in the } \\
\text { differentiation and regeneration of } \\
\text { Notch signaling-prohibited hair } \\
\text { cells from mouse cochlea }\end{array}$ & miR-183 & Positive & $\begin{array}{l}\text { Mouse, } \\
\text { cell culture, } \\
\text { organ culture }\end{array}$ & in vitro transfection & $\begin{array}{l}\text { Regulating Notch } \\
\text { signaling }\end{array}$ & $\mathrm{N} / \mathrm{A}$ & $\begin{array}{l}\text { Inhibition of the Notch } \\
\text { signaling pathway induces } \\
\text { miR-183 expression, which } \\
\text { participates in hair cell } \\
\text { differentiation and } \\
\text { regeneration }\end{array}$ & [183] \\
\hline 35 & $\begin{array}{l}\text { microRNA-183 is essential for hair } \\
\text { cell regeneration after neomycin } \\
\text { injury in zebrafish }\end{array}$ & $\begin{array}{c}\text { miR-183miR-182 } \\
\text { miR-96 }\end{array}$ & Positive & Zebrafish & Micro injection & N/A & N/A & $\begin{array}{l}\text { miR-183 cluster has a crucial } \\
\text { role in the regeneration of hair } \\
\text { cells in zebrafish larvae and it } \\
\text { can be a novel target for hair } \\
\text { cell regeneration }\end{array}$ & [184] \\
\hline 36 & $\begin{array}{l}\text { The intragenic mRNA-microRNA } \\
\text { regulatory network during } \\
\text { telogen-anagen hair follicle } \\
\text { transition in the cashmere goat }\end{array}$ & miR-195 & Positive & Goat & $\mathrm{N} / \mathrm{A}$ & $\begin{array}{c}\text { Regulating } \\
\text { Wnt } / \beta \text {-catenin signaling }\end{array}$ & $\begin{array}{l}\text { SMAD2 } \\
\text { FZD6 }\end{array}$ & $\begin{array}{l}\text { miR-195 plays a crucial role in } \\
\text { the regulation of HF initiation }\end{array}$ & [185] \\
\hline 37 & $\begin{array}{c}\text { miR-195-5p regulates hair follicle } \\
\text { inductivity of dermal papilla cells } \\
\text { by suppressing Wnt } / \beta \text {-catenin } \\
\text { activation }\end{array}$ & miR-195-5p & Negative & $\begin{array}{l}\text { Scalp specimen, } \\
\text { cell culture }\end{array}$ & in vitro transfection & $\begin{array}{c}\text { Inhibiting } \\
\text { Wnt/ } \beta \text {-catenin signaling }\end{array}$ & LRP6 & $\begin{array}{c}\text { miR-195-5p inhibits } \\
\text { Wnt/ } \beta \text {-catenin activation by } \\
\text { targeting LRP6 }\end{array}$ & [186] \\
\hline 38 & $\begin{array}{l}\text { The microRNA- } 200 \text { family } \\
\text { coordinately regulates cell } \\
\text { adhesion and proliferation in hair } \\
\text { morphogenesis }\end{array}$ & miR-200 & Positive & $\begin{array}{l}\text { Mouse, } \\
\text { cell culture }\end{array}$ & in vitro transfection & $\begin{array}{l}\text { Regulating Hippo/Yap } \\
\text { signaling }\end{array}$ & $\begin{array}{l}\text { CCNG2, CFL2, } \\
\text { SNAI2, SEC23A, } \\
\text { YWHAB, FAT1, } \\
\text { PTK2, CDC42, CRK, } \\
\text { ROCK2, WASL, } \\
\text { ACTN1 }\end{array}$ & $\begin{array}{l}\text { miR-200 family has a critical } \\
\text { function in mammalian skin } \\
\text { development via regulation of } \\
\text { cell adhesion and orientation } \\
\text { in the hair germ }\end{array}$ & [187] \\
\hline 39 & $\begin{array}{l}\text { miR-203 is involved in } \\
\text { osteoporosis by regulating DKK1 } \\
\text { and inhibiting osteogenic } \\
\text { differentiation of MSCs }\end{array}$ & & $\mathrm{N} / \mathrm{A}$ & $\begin{array}{l}\text { Human, } \\
\text { cell culture }\end{array}$ & in vitro transfection & $\begin{array}{c}\text { Activating } \\
\text { Wnt/ } \beta \text {-catenin signaling }\end{array}$ & DKK1 & $\begin{array}{l}\text { miR-203 by regulating DKK1 } \\
\text { expression promotes the } \\
\text { differentiation of rat MSCs } \\
\text { into osteoblast-like cells }\end{array}$ & [96] \\
\hline 40 & $\begin{array}{l}\text { Overexpression of miR-203 } \\
\text { increases the sensitivity of NSCLC } \\
\text { A549/H460 cell lines to cisplatin } \\
\text { by targeting Dickkopf-1 }\end{array}$ & miR-203 & N/A & $\begin{array}{c}\text { Human advanced } \\
\text { lung } \\
\text { adenocarcinoma } \\
\text { tissue, } \\
\text { cell culture, } \\
\text { mouse }\end{array}$ & $\begin{array}{c}\text { Subcutaneous } \\
\text { injection, } \\
\text { in vitro transfection }\end{array}$ & $\begin{array}{c}\text { Activating } \\
\text { Wnt } / \beta \text {-catenin signaling }\end{array}$ & DKK1 & $\begin{array}{l}\text { miR-203 by targeting the } \\
\text { 3'UTR of DKK1 increases } \\
\text { cisplatin sensitivity in } \\
\text { A549/H460 cell lines }\end{array}$ & [95] \\
\hline 41 & $\begin{array}{l}\text { RBM28, a protein deficient in ANE } \\
\text { syndrome, regulates hair follicle } \\
\text { growth via miR-203 and p63 }\end{array}$ & & Positive & $\begin{array}{l}\text { Cell culture, } \\
\text { organ culture }\end{array}$ & in vitro transfection & $\mathrm{N} / \mathrm{A}$ & P63 & $\begin{array}{l}\text { RBM28 directly regulates hair } \\
\text { growth by ameliorating the } \\
\text { expression or activity of } \\
\text { miR-203 that inhibits } \\
\text { transcription factor p63 }\end{array}$ & [188] \\
\hline
\end{tabular}


Table 2. Cont

\begin{tabular}{|c|c|c|c|c|c|c|c|c|c|}
\hline$\#$ & Study Title & miRNA & $\begin{array}{l}\text { Influence on Hair } \\
\text { Growth }\end{array}$ & Study Model & $\begin{array}{c}\text { Type of } \\
\text { Administration }\end{array}$ & Biological Function & Target Protein/Gene & Finding & Ref. \\
\hline 42 & $\begin{array}{l}\text { Expression of miRNA-203 and its } \\
\text { target gene in hair follicle cycle } \\
\text { development of Cashmere goat }\end{array}$ & & Regulatory & $\begin{array}{l}\text { Goat, } \\
\text { cell culture }\end{array}$ & in vitro transfection & N/A & DDOST, NAE1 & $\begin{array}{l}\text { miR-203 significantly } \\
\text { downregulates the expression } \\
\text { of DDOST and NAE1 and } \\
\text { regulates the HF development } \\
\text { in Cashmere goats }\end{array}$ & [189] \\
\hline 43 & $\begin{array}{l}\text { miR-203a-3p promotes loureirin } \\
\text { A-induced hair follicle stem cells } \\
\text { differentiation by targeting Smad1 }\end{array}$ & & Positive & $\begin{array}{l}\text { Rat, } \\
\text { cell culture }\end{array}$ & in vitro transfection & Inhibiting BMP signaling & SMAD1 & $\begin{array}{l}\text { miR-203a-3p inhibits SMAD1 } \\
\text { and promotes HFSCs } \\
\text { differentiation }\end{array}$ & [190] \\
\hline 44 & $\begin{array}{l}\text { The functions of ocu-miR-205 in } \\
\text { regulating hair follicle } \\
\text { development in Rex rabbits }\end{array}$ & miR-205 & Negative & Rabbit & Intradermal injection & $\begin{array}{l}\text { Regulating PI3K/Akt, } \\
\text { Wnt/ } \beta \text {-catenin, Notch, } \\
\text { BMP signaling pathways }\end{array}$ & NOG & $\begin{array}{l}\text { ocu-miR-205 promotes the } \\
\text { apoptosis of DP cells via } \\
\text { inhibiting the expression of } \\
\text { genes involved in the } \\
\text { PI3K/Akt, Wnt, and Notch } \\
\text { signaling pathways, and } \\
\text { activates the BMP signaling } \\
\text { pathway }\end{array}$ & [191] \\
\hline 45 & $\begin{array}{l}\text { MiR-214 regulates the human hair } \\
\text { follicle stem cell proliferation and } \\
\text { differentiation by targeting EZH2 } \\
\text { and Wnt } \beta \text {-catenin signaling way } \\
\text { in vitro }\end{array}$ & & Negative & $\begin{array}{l}\text { Scalp tissue, } \\
\text { cell culture }\end{array}$ & in vitro transfection & $\begin{array}{c}\text { Regulating } \\
\text { Wnt } / \beta \text {-catenin signaling }\end{array}$ & EZH2 & $\begin{array}{c}\text { Overexpression of miR-214 } \\
\text { decreases the expression of } \\
\text { EZH2, } \beta \text {-catenin, and TCF-4, } \\
\text { while downregulation of } \\
\text { miR-214 promotes the } \\
\text { proliferation and } \\
\text { differentiation of HFSCs }\end{array}$ & [192] \\
\hline 46 & $\begin{array}{l}\text { MicroRNA-214 controls skin and } \\
\text { hair follicle development by } \\
\text { modulating the activity of the Wnt } \\
\text { pathway }\end{array}$ & $\operatorname{miR}-214$ & Negative & $\begin{array}{l}\text { Mice, } \\
\text { cell culture }\end{array}$ & in vitro transfection & $\begin{array}{c}\text { Inhibiting } \\
\text { Wnt } / \beta \text {-catenin signaling }\end{array}$ & $\beta$-catenin & $\begin{array}{c}\text { miR-214 regulates the Wnt } \\
\text { signaling pathway and } \\
\beta \text {-catenin expression in the } \\
\text { developing and postnatal skin } \\
\text { and HFs }\end{array}$ & [75] \\
\hline 47 & $\begin{array}{l}\text { DNMT1-mediated methylation } \\
\text { inhibits microRNA-214-3p and } \\
\text { promotes hair follicle stem cell } \\
\text { differentiate into adipogenic } \\
\text { lineages }\end{array}$ & & Negative & $\begin{array}{l}\text { Scalp tissue, } \\
\text { cell culture }\end{array}$ & in vitro transfection & N/A & DNMT1, MAPK1 & $\begin{array}{c}\text { Expression of DNMT1, } \\
\text { MAPK1, and miR-214-3p in } \\
\text { HFSc are negatively } \\
\text { correlated. DNMT1 promotes } \\
\text { adipogenesis of HFSc by } \\
\text { mediating miR-214- } \\
\text { 3p/MAPK1/p-ERK1/2 } \\
\text { axis }\end{array}$ & [193] \\
\hline
\end{tabular}


Table 2. Cont

\begin{tabular}{|c|c|c|c|c|c|c|c|c|c|}
\hline \# & Study Title & miRNA & $\begin{array}{l}\text { Influence on Hair } \\
\text { Growth }\end{array}$ & Study Model & $\begin{array}{c}\text { Type of } \\
\text { Administration }\end{array}$ & Biological Function & Target Protein/Gene & Finding & Ref. \\
\hline 48 & $\begin{array}{l}\text { Dermal exosomes containing } \\
\text { miR-218-5p promote hair } \\
\text { regeneration by regulating } \\
\beta \text {-catenin signaling }\end{array}$ & \multirow[t]{3}{*}{ miR-218-5p } & Positive & $\begin{array}{l}\text { Mouse, } \\
\text { cell culture }\end{array}$ & $\begin{array}{l}\text { Subcutaneous } \\
\text { injection }\end{array}$ & $\begin{array}{c}\text { Activating } \\
\text { Wnt } \beta \text {-catenin signaling }\end{array}$ & SFRP2 & $\begin{array}{c}\text { miR-218-5p ameliorates HF } \\
\text { development by } \\
\text { downregulating SFRP2 and } \\
\text { promoting } \beta \text {-catenin. } \\
\text { miR-218-5p-overexpressed } \\
\text { exosomes lead to the onset of } \\
\text { anagen } \\
\end{array}$ & {$[77]$} \\
\hline 49 & $\begin{array}{l}\text { miR-218-5p regulates skin and hair } \\
\text { follicle development through } \\
\text { Wnt/ } \beta \text {-catenin signaling pathway } \\
\text { by targeting SFRP2 }\end{array}$ & & Positive & $\begin{array}{l}\text { Rabbit, } \\
\text { cell culture }\end{array}$ & in vitro transfection & $\begin{array}{c}\text { Activating } \\
\text { Wnt/ } \beta \text {-catenin signaling }\end{array}$ & SFRP2 & $\begin{array}{l}\text { miR-218-5p enhances the Wnt } \\
\text { signaling pathway by } \\
\text { targeting SFRP2 and induces } \\
\text { HF development }\end{array}$ & {$[76]$} \\
\hline 50 & $\begin{array}{l}\text { Osteogenic differentiation of } \\
\text { fibroblast-like synovial cells in } \\
\text { rheumatoid arthritis is induced by } \\
\text { microRNA-218 through a } \\
\text { ROBO/Slit pathway }\end{array}$ & & $\mathrm{N} / \mathrm{A}$ & Synovial tissues & in vitro transfection & $\begin{array}{c}\text { Activating } \\
\text { Wnt/ } \beta \text {-catenin signaling }\end{array}$ & ROBO1 & $\begin{array}{l}\text { miR-218 promotes the } \\
\text { osteogenic differentiation of } \\
\text { rheumatoid arthritis } \\
\text { fibroblast-like synovial cells } \\
\text { by targeting ROBO1 and } \\
\text { suppressing DKK1 }\end{array}$ & [153] \\
\hline 51 & $\begin{array}{l}\text { Defining microRNA signatures of } \\
\text { hair follicular stem and progenitor } \\
\text { cells in healthy and androgenic } \\
\text { alopecia patients }\end{array}$ & miR-324-3p & Positive & $\begin{array}{l}\text { Scalp sample, } \\
\text { cell culture }\end{array}$ & in vitro transfection & $\begin{array}{l}\text { Regulating MAPK, } \\
\text { TGF- } \beta \text { signaling } \\
\text { pathways }\end{array}$ & $\begin{array}{l}\text { REL A, HSP A2, } \\
\text { MAPK1 } 1 / 3 \text {, TGF- } \beta 3\end{array}$ & $\begin{array}{l}\text { miR-324-3p regulates } \\
\text { pathways implicated in HF } \\
\text { growth and development }\end{array}$ & [194] \\
\hline 52 & $\begin{array}{l}\text { MiR-92a-1-5p and miR-328-3p are } \\
\text { upregulated in skin of female } \\
\text { pattern hair loss patients }\end{array}$ & $\begin{array}{l}\operatorname{miR}-328-3 p \\
\text { miR-92a-1-5p }\end{array}$ & Negative & Human & $\mathrm{N} / \mathrm{A}$ & $\begin{array}{l}\text { Implicating in multiple } \\
\text { signaling pathways that } \\
\text { are involved in FPHL }\end{array}$ & $\mathrm{N} / \mathrm{A}$ & $\begin{array}{l}\text { miR-92a-1-5p and miR-328-3p } \\
\text { are involved in many } \\
\text { signaling pathways and have } \\
\text { a negative effect on FPHL }\end{array}$ & [195] \\
\hline 53 & $\begin{array}{l}\text { LncRNA-PCAT1 maintains } \\
\text { characteristics of dermal papilla } \\
\text { cells and promotes hair follicle } \\
\text { regeneration by regulating } \\
\text { miR-329/Wnt10b axis }\end{array}$ & miR-329 & Negative & $\begin{array}{l}\text { Scalp sample, } \\
\text { mouse, } \\
\text { cell culture }\end{array}$ & in vitro transfection & $\begin{array}{c}\text { Inhibiting } \\
\text { Wnt/ } \beta \text {-catenin signaling }\end{array}$ & $\begin{array}{l}\text { Wnt10b, ALP, BMP2, } \\
\text { Versican, NCAM }\end{array}$ & $\begin{array}{c}\text { PCAT1 promotes DP cells' } \\
\text { proliferation via activating } \\
\text { Wnt/ } \beta \text {-catenin signaling, } \\
\text { while miR-329 negatively } \\
\text { affects DP cells }\end{array}$ & [196] \\
\hline 54 & $\begin{array}{l}\text { Chi-miR-370-3p regulates hair } \\
\text { follicle morphogenesis of Inner } \\
\text { Mongolian cashmere goats }\end{array}$ & miR-370-3p & Positive & $\begin{array}{l}\text { Goat, } \\
\text { cell culture }\end{array}$ & in vitro transfection & $\begin{array}{l}\text { Inhibiting TGF, FGF } \\
\text { signaling }\end{array}$ & TGF- $\beta$ R2, FGFR2 & $\begin{array}{l}\text { Chi-miR-370-3p inhibits the } \\
\text { proliferation of epithelial cells } \\
\text { and dermal fibroblasts via } \\
\text { targeting FGFR2 and } \\
\text { TGF- } \beta \text { R2, as well as induces } \\
\text { HF morphog1enesis }\end{array}$ & [197] \\
\hline
\end{tabular}


Table 2. Cont

\begin{tabular}{|c|c|c|c|c|c|c|c|c|c|}
\hline$\#$ & Study Title & miRNA & $\begin{array}{l}\text { Influence on Hair } \\
\text { Growth }\end{array}$ & Study Model & $\begin{array}{c}\text { Type of } \\
\text { Administration }\end{array}$ & Biological Function & Target Protein/Gene & Finding & Ref. \\
\hline 55 & $\begin{array}{l}\text { Differential expression analysis of } \\
\text { balding and nonbalding dermal } \\
\text { papilla microRNAs in male pattern } \\
\text { baldness with a microRNA } \\
\text { amplification profiling method }\end{array}$ & $\begin{array}{l}\operatorname{miR}-410 \\
\text { miR-221 } \\
\text { miR-125b } \\
\text { miR-106a }\end{array}$ & Negative & $\begin{array}{l}\text { Human, } \\
\text { cell culture }\end{array}$ & N/A & N/A & N/A & $\begin{array}{c}\text { miR-221, miR-125b, miR-106a, } \\
\text { and miR-410 are significantly } \\
\text { upregulated in balding papilla } \\
\text { cells and they may participate } \\
\text { in the pathogenesis of male } \\
\text { pattern baldness }\end{array}$ & [151] \\
\hline 56 & $\begin{array}{l}\text { LncRNA-XIST promotes dermal } \\
\text { papilla induced hair follicle } \\
\text { regeneration by targeting miR-424 } \\
\text { to activate hedgehog signaling }\end{array}$ & $\mathrm{miR}-424$ & Negative & $\begin{array}{l}\text { Mouse, } \\
\text { cell culture }\end{array}$ & in vitro transfection & Inhibiting SHH signaling & $\begin{array}{l}\text { ALP, Versican, } \\
\text { NCAM, GLI1/2 }\end{array}$ & $\begin{array}{l}\text { miR-424 is sponged by XIST, } \\
\text { which promotes SHH } \\
\text { signaling and facilitates HF } \\
\text { regeneration }\end{array}$ & [198] \\
\hline
\end{tabular}

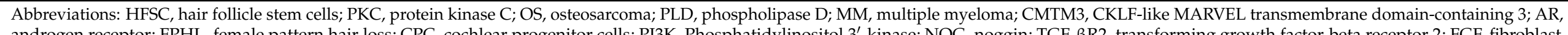

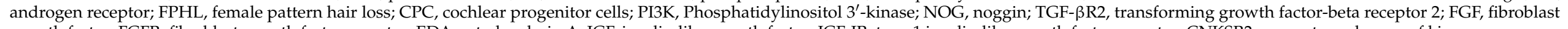

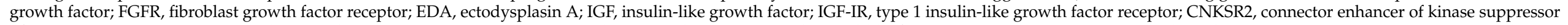

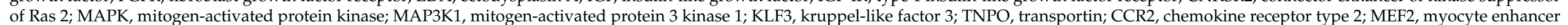

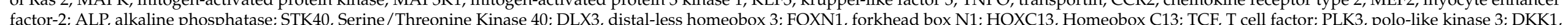

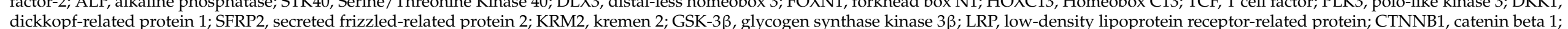

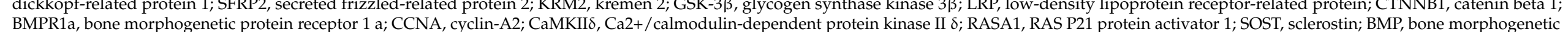

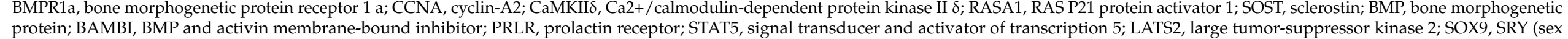

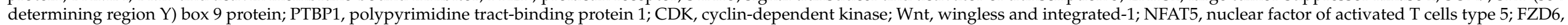

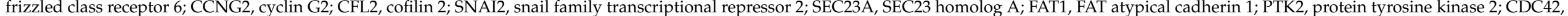

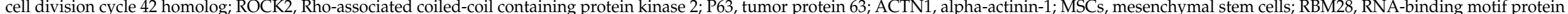

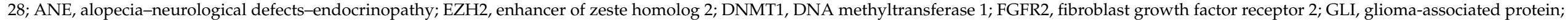
lncRNA, long noncoding RNA; XIST, X-inactive-specific transcript; $\mathrm{SHH}$, sonic hedgehog; N/A, not applicable. 
miRNAs are greatly multifunctional agents and the evidence from different sources is often puzzling, e.g., chi-miR-130-5p positively affects the Zhongwei goat hair development [177], while the member of the same miRNA family, miR-130b-3p, negatively influences the hair growth in Cashmere goats [176]. miR-130b-3p targets Wnt10a [176], while according to another study, it targets DKK1 in melanoma cells [91]. Thus, before formulating the suitable miRNA candidates for hair growth regulation, in-depth research is required on each possible target miRNA. The general mechanism of how miRNAs might promote hair growth is provided in Figure 6. miRNAs that are considered to be strongly involved in hair morphogenesis regulation are discussed below.

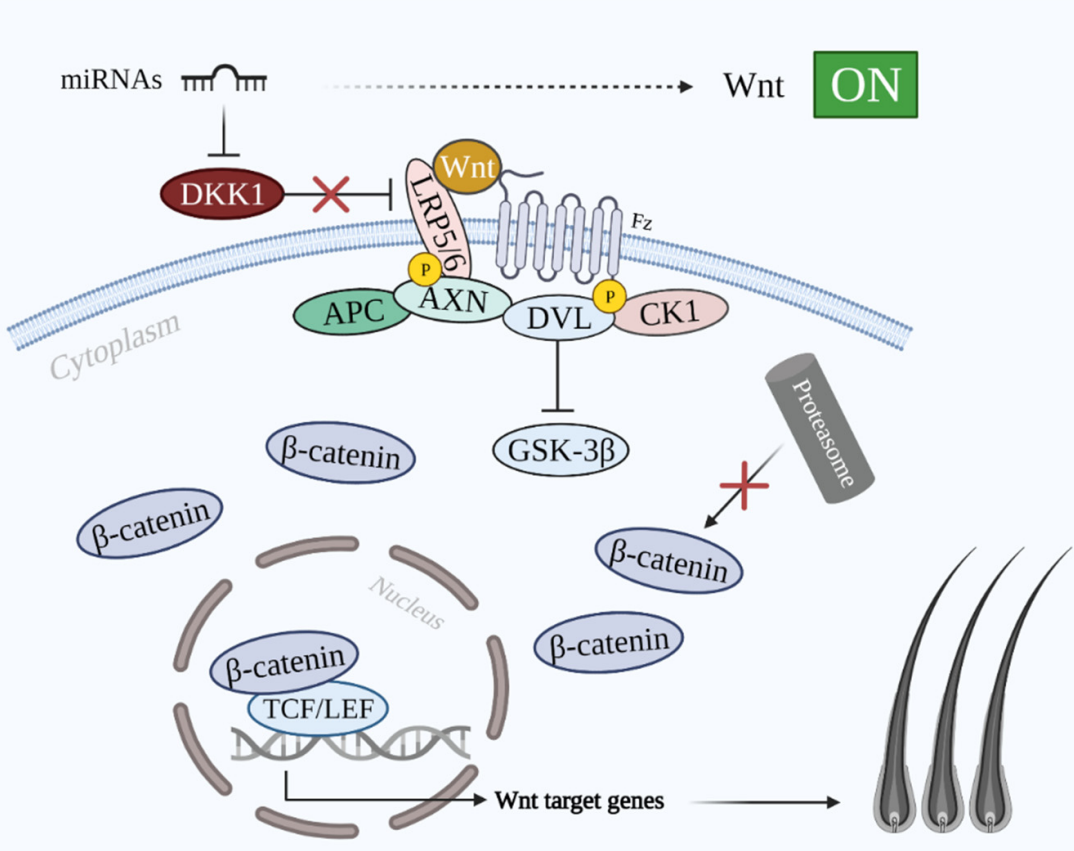

Figure 6. Schematic illustration of miRNAs role in hair growth. miRNAs targeting DKK1 allow Wnt to bind LRP5/ 6 and Fz to activate the signaling pathway and promote hair growth. Abbreviations: DKK1, dickkopf-related protein 1; Wnt, wingless and integrated-1; Fz, frizzled; LRP5/6, low-density lipoprotein receptor-related proteins 5/6; GSK-3 $\beta$, glycogen synthase kinase $3 \beta$; CK1, casein kinase 1; DVL, dishevelled; APC, adenomatous polyposis coli; TCF/LEF, T-cell factor/lymphoid enhancer factor.

\section{1. $m i R-29$}

miRNAs are versatile in terms of gene regulation. At the same time, the same miRNA targets a number of proteins. miR-29a is an example of accommodating diverse functions. miR-29s are encoded by two gene clusters and are transcribed by RNA polymerase II. The miR-29 family comprises three mature members: miR-29a, miR-29b, and miR-29c [199]. The seed region, which is a conserved sequence of the miRNA that perfectly binds to the target region of mRNA, is common for miR-29 family members. Hence, the predicted target genes largely overlap. Nevertheless, miR-29s exhibit different regulations, and thus, their functions may be different from each other [199]. These miRNAs accommodate diverse functions. Therefore, they are involved in various health conditions and studied extensively, e.g., miR-29s have elicited both oncogenic and tumor-suppressive functions. Particularly, miR-29b-1-5p was found to be downregulated in human breast cancer tissues, while miR$29 b-3 p$ was remarkably overexpressed in the human breast cancer cell line. Moreover, its inhibition was correlated with decreased cell viability, migration, and invasion [200].

The studies have demonstrated that miR-29a inhibits the expression of DKK1, KRM2, and SFRP2, and activates Wnt/ $\beta$-catenin signaling [164,167]. Hsu et al. demonstrated 
that the gain of miR-29a in diabetic mice is positively correlated with $\beta$-catenin levels, and negatively associated with the DKK1 levels, indicating that miR-29a is a regulator of DKK1 and, hence, the Wnt/ $\beta$-catenin signaling pathway [166]. Indeed, other studies also substantiate the same phenomenon in different sample types [84,164,165]. Based on this, one may presume that miR-29a is implicated in the hair growth cycle, particularly in the promotion of hair growth. In fact, Zhu et al. have demonstrated that miR-29a targets and inhibits the expression of DKK1, KRM2, and SFRP2 in vivo and in vitro. These proteins are involved in the inactivation of Wnt/ $\beta$-catenin signaling onset. Thus, miR-29a seems to be the candidate for studies focusing on developing AGA treatment strategies [167]. However, according to Ge et al., miR-29a/b1 overexpression inhibits the lineage of mice hair follicle stem cells (HFSCs). Additionally, the authors claim that miR-29a/b1 inhibits LRP, which represses the Wnt/ $\beta$-catenin signaling and results in hair loss [168]. Hence, the principle of the mechanism still needs to be clarified. Mardaryev et al. have studied the altered expressions of numerous miRNAs in the skin of mice during the different stages of the hair cycle. As a result, miR-29a expression was found to be dramatically downregulated during the anagen phase compared to the telogen phase in mice [170]. Although the abovementioned evidence seems paradoxical, miR-29 might not be excluded as a potentially beneficial agent for hair growth in AGA. Consequently, despite the fact that miR-29a's impact differs in cell types, its inhibitory effect on DKK1 expression remains unchanged, which leads to the activation of Wnt/ $\beta$-catenin signaling, and hence, hair growth.

\section{2. $m i R-31$}

miR-31 has a multifunctional capacity as it targets a number of genes and pathways [201]. It is highly expressed in the skin of mice during the anagen phase, compared to the catagen and especially the telogen phase [170]. Remarkably, an elevated level of miR-31 inhibited androgen receptor (AR) expression in vivo [201], which is crucial for ameliorating the AGA condition. Increased AR expression is associated with AGA [202,203]. Kim and Yoon have studied the expression of miR-31 in $\mathrm{Hr}^{\mathrm{Hp} p}$ (hairless mutant mice, 'hair-poor') mice. These mice exhibit hair loss and overexpression of protein hairless. The study demonstrated that the miR-31 level was significantly downregulated in the skin of $\mathrm{Hr} r^{\mathrm{Hp}} / \mathrm{Hr}^{\mathrm{Hp}}$ mice [204].

Chen et al. have studied the miR-31-5p regulatory role in osteosarcoma cells via the $W n t / \beta$-catenin signaling pathway. The study demonstrated that miR-31-5p targets AXIN1, which is part of the destruction complex and takes part in the reduction of $\beta$-catenin levels, and thus inactivates the canonical Wnt/ $\beta$-catenin signaling pathway. Thereby, the downregulation of miR-31-5p has an inhibitory effect on the proliferation of osteosarcoma cells via overexpression of AXIN1 [171]. Except for the AXIN1, it targets other factors that are implicated in Wnt/ $\beta$-catenin signaling, e.g., DKK1 and GSK-3 $\beta$ [205]. Indeed, $\mathrm{Lv}$ et al. have also stated that miR-31 activates the Wnt/ $\beta$-catenin signaling pathway via inhibiting DKK1 in mammary stem cell-enriched mammary basal cell population and in mammary tumors [85]. Apart from activating Wnt/ $\beta$-catenin signaling, miR-31 inhibits BMP and TGF- $\beta$ signaling pathways via targeting SMAD3 and SMAD4 in mice [206]. miR-31-5p overexpression is also found to exacerbate the proliferation of goat HFSCs and reduce apoptosis. Feng et al. has demonstrated that in Yangtze River Delta white goats, this regulatory mechanism is conditioned by the capacity of miR-31-5p to suppress RAS p21 protein activator 1 (RASA1) and increase mitogen-activated protein 3 kinase 1 (MAP3K1) levels. Thus, miR-31-5p is also involved in the mitogen-activated protein kinase (MAPK) signaling pathway and, as a result of its mechanism of action, hair growth takes place [169]. On the contrary, Luan et al. have studied the role of miR-31 in the hair growth of a transgenic mouse model and demonstrated that miR-31 impairs hair growth [172]. Additionally, miR-31 upregulation was found to be associated with HF aging in humans [207]. Thus, miR-31 seems to be an arguable candidate for AGA treatment. 


\section{3. $m i R-103 / 107$}

miR-103 is homologous to miR-107 [208]. miR-107 targets DKK1, while the expression of this Wnt/ $\beta$-catenin signaling antagonist is negatively correlated with the levels of miR107 , LRP5, and $\beta$-catenin in osteosarcoma tissues. It indicates that miR-107 is implicated in the $\mathrm{Wnt} / \beta$-catenin signaling pathway and may promote its onset [90]. Additionally, miR$103 / 107$ induces downregulation of AXIN2 and enhances the duration of Wnt/ $\beta$-catenin signaling as well as $\beta$-catenin abundance in the nucleus and $\beta$-catenin/TCF-dependent reporter activity, which promote multiple stem-like features of colorectal cancer [39]. Moreover, Liu et al. have demonstrated that miR-103a-3p reversed the effect of DKK1 in human bone marrow-derived mesenchymal stem cells [89].

These results support the assumption that miR-103/107 may promote hair growth via activating Wnt/ $\beta$-catenin signaling by targeting DKK1 and AXIN2, and therefore, these miRNAs deserve attention for further studies on AGA. In addition, Wang et al. have demonstrated that miRs-103/107 are expressed in the epidermis and HFs of mice and are downregulated with age. The authors suggest that miR-103/107 may be one of the key factors in sustaining the HF stemness with age [173].

\section{4. $m i R-152$}

Notably, miR-152 with miRNAs 199a, 126, 143, and 214 have been abundantly found in HFs $[73,156]$. Moreover, miR-152 is among the miRNAs that were found to be overexpressed more than three-fold in the mice HFs [156]. Likewise, Xu et al. have demonstrated that miR-152 levels were inversely correlated to the DKK1 expression level in multiple myeloma cells. Besides, the knockdown of miR-152 resulted in the upregulation of DKK1 mRNA and protein concentration. Moreover, aligning the sequences of miR-152 with the 3'UTR of DKK1 showed 9 binding sites. This, together with the result of transcriptional activity analysis, revealed that miR-152 directly regulates DKK1 gene expression [93]. Concurrently, Zhao et al. have demonstrated that overexpressed miR-152 targets and inhibits DKK1 levels in osteosarcoma cells [209]. It is noteworthy to mention that although miR-152 inhibits DKK1, and it is abundantly expressed in HFs [156], the microarray assay showed the lower levels of mmu-miR-152 expression in anagen and the highest expression in the telogen phase in mice skin [170]. Therefore, it can be presumed that miR-152 may regulate hair growth, but the influence is unclear and needs further investigation.

\section{5. $m i R-203$}

miR-203 is among the most abundantly expressed miRNAs in epidermis [156]. Interestingly, Cheng et al. have suggested that miR-203 targets the 3'UTR of DKK1 mRNA in tissues of lung adenocarcinoma and A549/H460 cell lines. Another study also demonstrated that miR-203 inhibits DKK1 expression via binding to its mRNA in rat mesenchymal stem cells [96]. As miR-203 is found to be expressed in HFs, it can be presumed that miR-203 may inhibit DKK1, and thus activate Wnt/ $\beta$-catenin signaling and promote hair growth via inducing anagen phase. Indeed, a study focusing on RNA-binding motif protein 28 (RBM28) showed that RBM28 promoted hair growth via modulating the activity of miR-203 in human HF organ cultures [188]. Furthermore, Ma et al. have revealed that miR-203 may regulate goat HF development [189]. miR-203a-3p is evidenced to inhibit SMAD1 in HFSC of Sprague Dawley (SD) rats [190], which positively influences on hair cycle as SMADs are known to inhibit HF differentiation and hair growth $[2,210]$.

\section{6. $m i R-218$}

miR-218 via its role in Wnt/ $\beta$-catenin signaling represents a hot spot molecule in cancer studies, as dysregulation of this miRNA is strongly associated with different cancers [211-216]. Except for the cancers, miR-218-5p plays an essential role in the HF and skin development again through $\mathrm{Wnt} / \beta$-catenin signaling by targeting and inhibiting SFRP2 - the antagonist of this signaling pathway [76]. Indeed, miR-218-5p is evidenced to promote HF development by inhibiting SFRP2. Treatment with the miR-218-5p mimic 
resulted in hair-regrowth in C57BL/6 mice, although the outcome was not as good as in case of treatment with exosomes containing this miRNA. This can be explained by the presence of multiple miRNAs in exosomes [77]. Besides, much depends on the delivery systems of miRNA. Delivery vectors are more developed for in vitro transfection than in vivo transfection. Although miR-218-5p seems a very promising candidate for hair restoration, it is still unclear whether this particular miRNA is capable to solely induce hair restoration in AGA because the abovementioned studies were performed on shaved/depilated dorsal skin of mice or HF organ culture obtained from C57BL/6 mice [77] or rabbits [76]. Additionally, there was no measurement of DKK1 conducted after the treatment with miRNA in any of those studies regarding the influence of miR-218 on hair growth. Intriguingly, upregulated miR-218-5p decreased DKK1 secretion in rheumatoid arthritis-fibroblast-like synovial cells [153]. This result also supports the idea that miR-218 may be one of the best candidates for AGA therapy. Therefore, it would be prudent to study the impact of miR-218 on DKK1 levels in the mouse model of human AGA induced by DHT treatment [27].

\section{Main Challenge: Delivery Systems}

RNA therapeutics need an effective technique to be delivered to the target cells, avoiding in vivo nuclease-mediated degradation. This is one of the major challenges in miRNA-based treatment along with specificity, stability, immune activation, and toxicity in vivo and in vitro [217]. Local delivery can be simply performed with the injection of naked RNA, while for systemic delivery, an effective delivery system is required [218]. Nucleic acids as well as other macromolecules are typically encapsulated with nanoparticles that are often modified with polyethylene glycol, cholesterol, or other moieties, or a special ligand is added to advance the uptake by the cell membrane. The encapsulated RNA molecule is then endocytosed by the cell. The nanoparticle is degraded, and the nucleic acid molecule is released into the cytoplasm [219]. Besides the nanoparticles, polyethyleneimine (PEI)-based delivery of miRNA is evidenced to be an effective approach. It has been used successfully for delivering miR-145 and miR-33a molecules in mice models [220]. PEI is a positively charged organic polymer that efficiently forms a complex with anionic RNA and provides an effective transfection in cells. Although branched and linear PEIs are used as miRNA delivery systems, they have limitations as well, such as low transfection efficiency and cytotoxicity. Poly (lactide-co-glycolide) (PLGA) is an FDA-approved biodegradable drug delivery system, however, due to the hydrophobic property, miRNA delivery is less efficient. Among polymer delivery carriers, poly (amidoamine) dendrimers are characterized with high transfection efficiency [221]. For studying the effect of miR-218-5p on hair regrowth in mice, as a delivery system, in vivo jetPEI was used effectively [77]. Compared with the PEI, in vivo jetPEI is more effective and safer, although it is relatively costly. As a non-viral vector, typically, lipid-based modified nanocarriers are used, e.g., lipofectamine [188], invivofectamine, oligofectamine, etc. [222]. The study has revealed the beneficial properties of argininocalix [4] arene, that seems to be an effective delivery system for miRNA therapeutics [223,224]. A promising candidate is lipid-based nanoparticles (LNP), that consist of the same component as the cell membrane and promote the uptake process [225,226]. Remarkably, LNP-based delivery of miR-634 has successfully reduced tumor xenograft growth in mice [227]. Evidently, solid lipid nanoparticles (SLNs) successfully work for delivering miR-34a for cancer stem cell therapy [228]. Moreover, the COVID-19 mRNA vaccine is also packed with LNP [229]. Thus, LNP application for miRNA delivery seems to be realized in the nearest future. However, LNPs also have disadvantages, such as the requirement of ultra-low-temperature storage [229]. Except for the non-viral delivery methods, there are viral delivery miRNA carrier systems, e.g., adenoviral, retroviral [230], lentiviral, and bacteriophage-based virus-like particle vectors [231]. However, viral vectors have disadvantages as well, e.g., the phage vector has a low loading capacity and needs sufficient studies, while in the case of lentiviral vectors, random genomic integration might result in the insertional mutation [231]. In terms of non-viral delivery systems, the exosome-based method is one of the most promising [231], although the difficulty of 
preparation hinders its development [232]. In hair growth studies, mostly lipofectamine (in vitro) $[7,76,177,189,190]$ and in vivo jetPEI [77] are used as delivery systems. Taken together, according to the present data, there are a number of effective delivery carriers for miRNAs, but along with the advantages, drawbacks such as stability, toxicity, localized delivery, and integrity of nucleic acid still exist.

\section{Concluding Remarks and Future Directions}

Collectively, DKK1 has a critical role in the development of human AGA. Inhibition of DKK1 levels in the balding area of the scalp in populations that are at high risk of developing AGA might prevent the further progression of this disorder. On the other hand, it might even overcome the problem of hair regrowth via stimulating $\mathrm{Wnt} / \beta$-catenin signaling. Therefore, assessment of DKK1-targeting miRNAs that are expressed in human HFs and involved in the Wnt / $\beta$-catenin signaling pathway may lay the groundwork for developing strategies of promoting hair regeneration and treatment of AGA. Nevertheless, further studies are needed to validate the described phenomenon. Additionally, miR-103/107, miR-203, and miR-218 among other miRNAs might represent the attractive therapeutic candidates for further studies focusing on modulation of the Wnt/ $\beta$-catenin signaling pathway via regulating DKK1. Prominently, the functional spectrum of miRNAs is wide. Although certain miRNAs are capable to inhibit the Wnt antagonist, they might also target other key molecules that are instrumental in the regulation of this pathway. miR-29a ideally exemplifies the described complexity $[167,168]$. Thus, in-depth studies are needed to select the optimal miRNA as a potential drug candidate. Furthermore, it is crucial to design such an approach extremely delicately as the Wnt/ $\beta$-catenin pathway is implicated in a myriad of biological processes and the intervention might trigger unfavorable consequences. Thus, an approach that implies the application of selected miRNAs that are delivered in HFs makes sense. Ultimately, miRNAs implicated in Wnt/ $\beta$-catenin signaling that target DKK1 should be the center of foci in further studies to elucidate their roles and to aid in advancing strategies of AGA treatment.

Author Contributions: P.G.W. and D.P. conceived the idea and designed the manuscript; N.R. and D.P. collected literature, wrote, edited, and iteratively reviewed the manuscript; C.L. revised the manuscript and contributed to making the table; F.X. revised the table; D.T. revised part of the manuscript; Y.H. reviewed and revised the manuscript. All authors have read and agreed to the published version of the manuscript.

Funding: This research was funded by the Department of Education of Guangdong Province Research Project, grant number 2020KZDZX1181, and Shenzhen Science and Technology Program, grant number KQTD20200909113758004.

Institutional Review Board Statement: Not applicable.

Informed Consent Statement: Not applicable.

Data Availability Statement: Not applicable.

Acknowledgments: Part of the figures were created with BioRender.com.

Conflicts of Interest: The authors declare no conflict of interest.

\section{References}

1. Chen, C.L.; Huang, W.Y.; Wang, E.H.C.; Tai, K.Y.; Lin, S.J. Functional complexity of hair follicle stem cell niche and therapeutic targeting of niche dysfunction for hair regeneration. J. Biomed. Sci. 2020, 27, 1-11. [CrossRef] [PubMed]

2. Choi, B.Y. Targeting wnt/ $\beta$-catenin pathway for developing therapies for hair loss. Int. J. Mol. Sci. 2020, 21, 4915. [CrossRef] [PubMed]

3. Grymowicz, M.; Rudnicka, E.; Podfigurna, A.; Napierala, P.; Smolarczyk, R.; Smolarczyk, K.; Meczekalski, B. Hormonal E ff ects on Hair Follicles. Int. J. Mol. Sci. 2020, 21, 5342. [CrossRef] [PubMed]

4. Houschyar, K.S.; Borrelli, M.R.; Tapking, C.; Popp, D.; Puladi, B.; Ooms, M.; Chelliah, M.P.; Rein, S.; Pförringer, D.; Thor, D.; et al. Molecular mechanisms of hair growth and regeneration: Current understanding and novel paradigms. Dermatology 2020, 236, 271-280. [CrossRef] [PubMed] 
5. Li, Y.H.; Zhang, K.; Ye, J.X.; Lian, X.H.; Yang, T. Wnt10b promotes growth of hair follicles via a canonical Wnt signalling pathway. Clin. Exp. Dermatol. 2011, 36, 534-540. [CrossRef]

6. Li, Y.H.; Zhang, K.; Yang, K.; Ye, J.X.; Xing, Y.Z.; Guo, H.Y.; Deng, F.; Lian, X.H.; Yang, T. Adenovirus-mediated wnt10b overexpression induces hair follicle regeneration. J. Investig. Dermatol. 2013, 133, 42-48. [CrossRef] [PubMed]

7. Xiong, Y.; Liu, Y.; Song, Z.; Hao, F.; Yang, X. Identification of Wnt/ $\beta$-catenin signaling pathway in dermal papilla cells of human scalp hair follicles: TCF4 regulates the proliferation and secretory activity of dermal papilla cell. J. Dermatol. 2014, 41, 84-91. [CrossRef]

8. Lin, W.; Xiang, L.; Shi, H.; Zhang, J.; Jiang, L.; Cai, P.; Lin, Z.; Lin, B.; Huang, Y.; Zhang, H.; et al. Fibroblast Growth Factors Stimulate Hair Growth through $\beta$-Catenin and Shh Expression in C57BL/6 Mice. Biomed Res. Int. 2015, 2015, 730139. [CrossRef]

9. Gentile, P.; Garcovich, S. Advances in Regenerative Stem Cell Therapy in Androgenic Alopecia and Hair Loss: Wnt Pathway, Growth-Factor, and Mesenchymal Stem Cell Signaling Impact Analysis on Cell Growth and Hair Follicle Development. Cells 2019, 8, 466. [CrossRef]

10. Kwack, M.H.; Sung, Y.K.; Chung, E.J.; Im, S.U.; Ahn, J.S.; Kim, M.K.; Kim, J.C. Dihydrotestosterone-inducible dickkopf 1 from balding dermal papilla cells causes apoptosis in follicular keratinocytes. J. Investig. Dermatol. 2008, 128, 262-269. [CrossRef]

11. Fawzi, M.M.T.; Mahmoud, S.B.; Shaker, O.G.; Saleh, M.A. Assessment of tissue levels of dickkopf-1 in androgenetic alopecia and alopecia areata. J. Cosmet. Dermatol. 2016, 15, 10-15. [CrossRef]

12. Kwack, M.H.; Kim, M.K.; Kim, J.C.; Sung, Y.K. Dickkopf 1 promotes regression of hair follicles. J. Investig. Dermatol. 2012, 132, 1554-1560. [CrossRef] [PubMed]

13. Premanand, A.; Rajkumari, B.R. Androgen modulation of Wnt/ $\beta$-catenin signaling in androgenetic alopecia. Arch. Dermatol. Res. 2018, 310, 391-399. [CrossRef] [PubMed]

14. Sferrazza, G.; Corti, M.; Brusotti, G.; Pierimarchi, P.; Temporini, C.; Serafino, A.; Calleri, E. Nature-derived compounds modulating Wnt/ $\beta$-catenin pathway: A preventive and therapeutic opportunity in neoplastic diseases. Acta Pharm. Sin. B 2020, 10, 1814-1834. [CrossRef] [PubMed]

15. Zhang, Y.; Wang, X. Targeting the Wnt/ $\beta$-catenin signaling pathway in cancer. J. Hematol. Oncol. 2020, 13, 165. [CrossRef]

16. Bao, J.; Yang, Y.; Xia, M.; Sun, W.; Chen, L. Wnt signaling: An attractive target for periodontitis treatment. Biomed. Pharmacother. 2021, 133, 110935. [CrossRef]

17. Krishnamurthy, N.; Kurzrock, R. Targeting the Wnt/beta-catenin pathway in cancer: Update on effectors and inhibitors. Cancer Treat. Rev. 2018, 62, 50-60. [CrossRef]

18. Huang, C.; Ye, Z.; Wan, J.; Liang, J.; Liu, M.; Xu, X.; Li, L. Secreted Frizzled-Related Protein 2 Is Associated with Disease Progression and Poor Prognosis in Breast Cancer. Dis. Markers 2019, 2019, 6149381. [CrossRef]

19. Zhu, G.; Song, J.; Chen, W.; Yuan, D.; Wang, W.; Chen, X.; Liu, H.; Su, H.; Zhu, J. Expression and Role of Dickkopf-1 (Dkk1) in Tumors: From the Cells to the Patients. Cancer Manag. Res. 2021, 13, 659-675. [CrossRef]

20. Choi, Y.S.; Zhang, Y.; Xu, M.; Yang, Y.; Ito, M.; Peng, T.; Cui, Z.; Nagy, A.; Hadjantonakis, A.K.; Lang, R.A.; et al. Distinct functions for Wnt $\beta$-Catenin in hair follicle stem cell proliferation and survival and interfollicular epidermal homeostasis. Cell Stem Cell 2013, 13, 720-733. [CrossRef]

21. Flores-hernández, E.; Velázquez, D.M.; Castañeda-patlán, M.C.; Fuentes-garcía, G.; Fonseca-camarillo, G.; Yamamoto-furusho, J.K.; Romero-Avila, M.T.; García-Sáinz, J.A.; Robles-Flores, M. Canonical and non-canonical Wnt signaling are simultaneously activated by Wnts in colon cancer cells. Cell. Signal. 2020, 72, 109636. [CrossRef] [PubMed]

22. Ng, L.F.; Kaur, P.; Bunnag, N.; Suresh, J.; Sung, I.C.H.; Tan, Q.H.; Gruber, J.; Tolwinski, N.S. WNT Signaling in Disease. Cells 2019, 8, 826. [CrossRef] [PubMed]

23. Zeng, P.; Yang, J.; Liu, L.; Yang, X.; Yao, Z.; Ma, C.; Zhu, H.; Su, J.; Zhao, Q.; Feng, K.; et al. ERK1/2 inhibition reduces vascular calcification by activating miR-126-3p-DKK1/LRP6 pathway. Theranostics 2021, 11, 1129-1146. [CrossRef] [PubMed]

24. Tosti, A.; Zaiac, M.N.; Canazza, A.; Sanchis-gomar, F.; Pareja-galeano, H.; Alis, R.; Lucia, A.; Emanuele, E. Topical application of the Wnt/ $\beta$-catenin activator methyl vanillate increases hair count and hair mass index in women with androgenetic alopecia. J. Cosmet. Dermatol. 2016, 15, 469-474. [CrossRef] [PubMed]

25. Zhang, Y.; Xu, J.; Jing, J.; Wu, X.; Lv, Z. Serum levels of androgen-associated hormones are correlated with curative effect in androgenic alopecia in young men. Med. Sci. Monit. 2018, 24, 7770-7777. [CrossRef]

26. Chen, X.; Liu, B.; Li, Y.; Han, L.; Tang, X.; Deng, W.; Lai, W. Dihydrotestosterone regulates hair growth through the Wnt/ $\beta$-catenin Pathway in C57BL/6 Mice and in vitro organ culture. Front. Pharmacol. 2020, 10, 1528. [CrossRef] [PubMed]

27. Fu, D.; Huang, J.; Li, K.; Chen, Y.; He, Y.; Sun, Y.; Guo, Y.; Du, L.; Qu, Q.; Miao, Y.; et al. Dihydrotestosterone-induced hair regrowth inhibition by activating androgen receptor in C57BL6 mice simulates androgenetic alopecia. Biomed. Pharmacother. 2021, 137, 111247. [CrossRef]

28. Kishimoto, J.; Burgeson, R.E.; Morgan, B.A. Wnt signaling maintains the hair-inducing activity of the dermal papilla. Genes Dev. 2000, 14, 1181-1185. [CrossRef]

29. Shin, H.R.; Kwack, M.H.; Shin, S.H.; Oh, J.W.; Kang, B.M.; Kim, A.A.; Kim, J.; Kim, M.K.; Kim, J.C.; Sung, Y.K. Identification of transcriptional targets of Wnt/ $\beta$-catenin signaling in dermal papilla cells of human scalp hair follicles: EP2 is a novel transcriptional target of Wnt3a. J. Dermatol. Sci. 2010, 58, 91-96. [CrossRef]

30. Xing, F.; Yi, W.J.; Miao, F.; Su, M.Y.; Lei, T.C. Baicalin increases hair follicle development by increasing canonical Wnt/ $\beta$-catenin signaling and activating dermal papillar cells in mice. Int. J. Mol. Med. 2018, 41, 2079-2085. [CrossRef] 
31. Lei, M.; Guo, H.; Qiu, W.; Lai, X.; Yang, T.; Randall, B.; Chuong, C.; Lian, X.; Yang, L. Modulating hair follicle size with Wnt10b-DKK1 pair during hair regeneration. Exp. Dermatol. 2015, 23, 407-413. [CrossRef] [PubMed]

32. Gemayel, R.; Chenette, E.J. $\beta$-catenin signalling in dermal papilla cells leads to a hairy situation. FEBS J. 2016, $283,2820-2822$. [CrossRef] [PubMed]

33. Rahmani, W.; Sinha, S.; Biernaskie, J. Immune modulation of hair follicle regeneration. npj Regen. Med. 2020, 5, 1-13. [CrossRef] [PubMed]

34. Schlake, T.; Sick, S. Canonical WNT Signalling Controls Hair Follicle Spacing. Cell Adh. Migr. 2007, 1, 149-151. [CrossRef]

35. Enshell-Seijffers, D.; Lindon, C.; Kashiwagi, M.; Morgan, B.A. $\beta$-catenin Activity in the Dermal Papilla Regulates Morphogenesis and Regeneration of Hair. Dev. Cell 2010, 18, 633-642. [CrossRef] [PubMed]

36. Rishikaysh, P.; Dev, K.; Diaz, D.; Shaikh Qureshi, W.M.; Filip, S.; Mokry, J. Signaling involved in hair follicle morphogenesis and development. Int. J. Mol. Sci. 2014, 15, 1647-1670. [CrossRef] [PubMed]

37. Kimelman, D.; Xu, W. $\beta$-catenin destruction complex: Insights and questions from a structural perspective. Oncogene 2006, 25, 7482-7491. [CrossRef]

38. Daniels, D.L.; Weis, W.I. $\beta$-catenin directly displaces Groucho/TLE repressors from Tcf/Lef in Wnt-mediated transcription activation. Nat. Struct. Mol. Biol. 2005, 12, 364-371. [CrossRef]

39. Chen, H.; Lang, Y.; Han-nan, L.; Liu, Y.; Liao, C.; Nana, A.W.; Yen, Y.; Chen, R. miR-103/107 prolong Wnt/ $\beta$-catenin signaling and colorectal cancer stemness by targeting Axin2. Sci. Rep. 2019, 9, 9687. [CrossRef]

40. Mahmoud, E.A.; Elgarhy, L.H.; Hasby, E.A.; Mohammad, L. Dickkopf-1 Expression in Androgenetic Alopecia and Alopecia Areata in Male Patients. Am. J. Dermatopathol. 2019, 41, 122-127. [CrossRef]

41. Kwack, M.H.; Ahn, J.S.; Jang, J.H.; Kim, J.C.; Sung, Y.K.; Kim, M.K. SFRP2 augments Wnt/ $\beta$-catenin signalling in cultured dermal papilla cells. Exp. Dermatol. 2016, 25, 813-815. [CrossRef]

42. Paul, S.; Licona-Vázquez, I.; Serrano-Cano, F.I.; Frías-Reid, N.; Pacheco-Dorantes, C.; Pathak, S.; Chakraborty, S.; Srivastava, A. Current insight into the functions of microRNAs in common human hair loss disorders: A mini review. Hum. Cell 2021, 34, 1040-1050. [CrossRef]

43. Niehrs, C. Function and biological roles of the Dickkopf family of Wnt modulators. Oncogene 2006, 25, 7469-7481. [CrossRef]

44. Seib, D.R.M.; Corsini, N.S.; Ellwanger, K.; Plaas, C.; Mateos, A.; Pitzer, C.; Niehrs, C.; Celikel, T.; Martin-Villalba, A. Loss of dickkopf-1 restores neurogenesis in old age and counteracts cognitive decline. Cell Stem Cell 2013, 12, 204-214. [CrossRef] [PubMed]

45. Dovjak, P.; Dorfer, S.; Föger-Samwald, U.; Kudlacek, S.; Marculescu, R.; Pietschmann, P. Serum levels of sclerostin and dickkopf-1: Effects of age, gender and fracture status. Gerontology 2014, 60, 493-501. [CrossRef] [PubMed]

46. Ho, C.H.; Sood, T.; Zito, P.M. Androgenetic Alopecia; StatPearls Publishing: Treasure Island, FL, USA, 2021.

47. Yang, C.C.; Hsieh, F.N.; Lin, L.Y.; Hsu, C.K.; Sheu, H.M.; Chen, W. Higher body mass index is associated with greater severity of alopecia in men with male-pattern androgenetic alopecia in Taiwan: A cross-sectional study. J. Am. Acad. Dermatol. 2014, 70, 297-302.e1. [CrossRef]

48. Morinaga, H.; Mohri, Y.; Grachtchouk, M.; Asakawa, K.; Matsumura, H.; Oshima, M.; Takayama, N.; Kato, T.; Nishimori, Y.; Sorimachi, Y.; et al. Obesity accelerates hair thinning by stem cell-centric converging mechanisms. Nature 2021, 595, $266-271$. [CrossRef] [PubMed]

49. Ali, H.; Zmuda, J.M.; Cvejkus, R.K.; Kershaw, E.E.; Kuipers, A.L.; Oczypok, E.A.; Wheeler, V.; Bunker, C.H.; Miljkovic, I. Wnt pathway inhibitor DKK1: A potential novel biomarker for adiposity. J. Endocr. Soc. 2019, 3, 488-495. [CrossRef] [PubMed]

50. Colditz, J.; Picke, A.; Hofbauer, L.C.; Rauner, M. Contributions of Dickkopf-1 to Obesity-Induced Bone. J. Bone Miner. Res. 2020, 4, 1-14. [CrossRef]

51. Kim, M.J.; Lim, C.; Lee, J.Y.; Im, K.R.; Yoon, K.S.; Song, J.M. Visible-to-near IR quantum dot-based hypermulticolor high-content screening of herbal medicines for the efficacy monitoring of hair growth promotion and hair loss inhibition. J. Biomol. Screen. 2013, 18, 462-473. [CrossRef]

52. Zhou, L.; Wang, H.; Jing, J.; Yu, L.; Wu, X.; Lu, Z. Morroniside regulates hair growth and cycle transition via activation of the Wnt/ $\beta$-catenin signaling pathway. Sci. Rep. 2018, 8, 13785. [CrossRef] [PubMed]

53. Cselenyi, C.S.; Lee, E. Context-dependent activation or Inhibition of Wnt-beta-catenin signaling by kremen. Sci. Signal. 2008, 1, pe10. [CrossRef] [PubMed]

54. Rothbächer, U.; Lemaire, P. Crème de la Kremen of Wnt signalling inhibition. Nat. Cell Biol. 2002, 4, E172-E173. [CrossRef]

55. Luo, J.; Chen, M.; Liu, Y.; Xie, H.; Yuan, J.; Zhou, Y.; Ding, J.; Deng, Z.; Li, J. Nature-derived lignan compound VB-1 exerts hair growth-promoting effects by augmenting Wnt/ $\beta$-catenin signaling in human dermal papilla cells. PeerJ 2018, 6, e4737. [CrossRef]

56. Lee, Y.; Kim, S.U.N.A.; Hong, Y.D.; Park, B.C.; Na, Y. Panax ginseng extract antagonizes the effect of DKK-1-induced catagen-like changes of hair follicles. Int. J. Mol. Med. 2017, 40, 1194-1200. [CrossRef] [PubMed]

57. Kim, Y.E.; Choi, H.C.; Nam, G.; Choi, B.Y. Costunolide promotes the proliferation of human hair follicle dermal papilla cells and induces hair growth in C57BL/ 6 mice. J. Cosmet. Dermatol. 2019, 18, 414-421. [CrossRef]

58. Zhang, H.; Shi, Q.; Nan, W.; Wang, Y.; Wang, S.; Yang, F.; Li, G. Ginkgolide B and bilobalide promote the growth and increase $\beta$-catenin expression in hair follicle dermal papilla cells of American minks. BioFactors 2019, 45, 950-958. [CrossRef] [PubMed]

59. Jeong, H.S.; Kwack, M.H.; Kim, M.K.; Kim, J.C.; Sung, Y.K. Attenuation of Dickkopf 1-Induced Hair Growth Inhibition in Cultured Human Hair Follicles by Tianeptine. Ann. Dermatol. 2017, 29, 102-105. [CrossRef] 
60. Feinbaum, R.; Ambros, V.; Lee, R. The C. elegans Heterochronic Gene lin-4 Encodes Small RNAs with Antisense Complementarity to lin-14. Cell 1993, 75, 843-854.

61. Pasquinelli, A.E.; Reinhart, B.J.; Slack, F.; Martindale, M.Q.; Kuroda, M.I.; Maller, B.; Hayward, D.C.; Ball, E.E.; Degnan, B.; Mu, P.; et al. Conservation of the sequence and temporal expression of let-7 heterochronic regulatory RNA. Nature 2000, 408, 86-89. [CrossRef]

62. Gazerani, P. Current Evidence on Potential Uses of MicroRNA Biomarkers for Migraine: From Diagnosis to Treatment. Mol. Diagn. Ther. 2019, 23, 681-694. [CrossRef] [PubMed]

63. Ahmed, S.P.; Castresana, J.S.; Shahi, M.H. Glioblastoma and MiRNAs. Cancers 2021, 13, 1581. [CrossRef] [PubMed]

64. Bouchie, A. First microRNA mimic enters clinic. Nat. Biotechnol. 2013, 31, 577. [CrossRef]

65. Chakraborty, C.; Sharma, A.R.; Sharma, G.; Lee, S.S. Therapeutic advances of miRNAs: A preclinical and clinical update. J. Adv. Res. 2021, 28, 127-138. [CrossRef]

66. Zhang, S.; Cheng, Z.; Wang, Y.; Han, T. The Risks of miRNA Therapeutics: In a Drug Target Perspective. Drug Des. Dev. Ther. 2021, 15, 721-733. [CrossRef] [PubMed]

67. Mullard, A. 2018 FDA drug approvals. Nat. Rev. Drug Discov. 2019, 18, 85-89. [CrossRef] [PubMed]

68. Mullard, A. 2019 FDA drug approvals. Nat. Rev. Drug Discov. 2020, 19, 79-84. [CrossRef] [PubMed]

69. Zhang, M.M.; Bahal, R.; Rasmussen, T.P.; Manautou, J.E.; Zhong, X.B. The growth of siRNA-based therapeutics: Updated clinical studies. Biochem. Pharmacol. 2021, 189, 114432. [CrossRef]

70. Ozcan, G.; Ozpolat, B.; Coleman, R.L.; Sood, A.K.; Lopez-Berestein, G. Preclinical and clinical development of siRNA-based therapeutics. Adv. Drug Deliv. Rev. 2015, 87, 108-119. [CrossRef]

71. Hoy, S.M. Patisiran: First Global Approval. Drugs 2018, 78, 1625-1631. [CrossRef]

72. Ledford, H. Gene-silencing drug approved Outrage over changes to EPA chemical assessments. Nature 2018, 560, $291-292$. [CrossRef]

73. Ning, M.S.; Andl, T. Control by a hair's breadth: The role of microRNAs in the skin. Cell. Mol. Life Sci. 2013, 70, 1149-1169. [CrossRef]

74. Zhang, Y.; Xia, S.; Wang, T.; Wang, S.; Yuan, D.; Li, F.; Wang, X. Chi-miR-30b-5p inhibits dermal papilla cells proliferation by targeting CaMKII $\delta$ gene in cashmere goat. BMC Genom. 2020, 21, 430. [CrossRef] [PubMed]

75. Ahmed, M.I.; Alam, M.; Emelianov, V.U.; Poterlowicz, K.; Patel, A.; Sharov, A.A.; Mardaryev, A.N.; Botchkareva, N. V MicroRNA214 controls skin and hair follicle development by modulating the activity of the Wnt pathway. J. Cell Biol. 2014, 207, 549-567. [CrossRef]

76. Zhao, B.; Chen, Y.; Yang, N.; Chen, Q.; Wu, X. miR-218-5p regulates skin and hair follicle development through Wnt/ $\beta$-catenin signaling pathway by targeting SFRP2. J. Cell. Physiol. 2019, 234, 1-13. [CrossRef]

77. Hu, S.; Li, Z.; Lutz, H.; Huang, K.; Su, T.; Cores, J.; Dinh, P.U.C.; Cheng, K. Dermal exosomes containing miR-218-5p promote hair regeneration by regulating $\beta$-catenin signaling. Sci. Adv. 2020, 6, eaba1685. [CrossRef] [PubMed]

78. Andl, T.; Reddy, S.T.; Gaddapara, T.; Millar, S.E. WNT signals are required for the initiation of hair follicle development. Dev. Cell 2002, 2, 643-653. [CrossRef]

79. Li, S.; Yin, Y.; Yao, L.; Lin, Z.; Sun, S.; Zhang, J.; Li, X. TNF- $\alpha$ treatment increases DKK1 protein levels in primary osteoblasts via upregulation of DKK1 mRNA levels and downregulation of miR-335-5p. Mol. Med. Rep. 2020, 22, 1017-1025. [CrossRef] [PubMed]

80. Zhang, J.; Tu, Q.; Bonewald, L.F.; He, X.; Stein, G.; Lian, J.; Chen, J. Effects of miR-335-5p in modulating osteogenic differentiation by specifically downregulating Wnt antagonist DKK1. J. Bone Miner. Res. 2011, 26, 1953-1963. [CrossRef] [PubMed]

81. Michel, L.D.; Reygagne, P.; Benech, P.; Scalvino, S.; So, S.L.K.; Hamidou, Z.; Bianovici, S.; Pouch, J.; Ducos, B.; Bonnet, M.; et al. Study of gene expression alteration in male androgenetic alopecia: Evidence of predominant molecular signalling pathways. Br. J. Dermatol. 2017, 177, 1322-1336. [CrossRef]

82. Wang, Z.; Wang, J.; Chen, Z.; Wang, K.; Shi, L. MicroRNA-1-3p inhibits proliferation and migration of oral squamous cell carcinoma cells by targeting DKK1. Biochem. Cell Biol. 2018, 96, 355-364. [CrossRef]

83. Mirfazeli, E.S.; Arefian, E.; Nadri, S.; Rezazadeh Valojerdi, R.; Kehtari, M.; Zeynali, B. DKK1 expression is suppressed by miR-9 during induced dopaminergic differentiation of human trabecular meshwork mesenchymal stem cells. Neurosci. Lett. 2019, 707, 134250. [CrossRef] [PubMed]

84. Li, C.; Zhang, P.; Gu, J. miR-29a modulates tumor necrosis factor- $\alpha$-induced osteogenic inhibition by targeting Wnt antagonists. Dev. Growth Differ. 2015, 57, 264-273. [CrossRef] [PubMed]

85. Lv, C.; Li, F.; Li, X.; Tian, Y.; Zhang, Y.; Sheng, X.; Song, Y.; Meng, Q.; Yuan, S.; Luan, L.; et al. MiR-31 promotes mammary stem cell expansion and breast tumorigenesis by suppressing Wnt signaling antagonists. Nat. Commun. 2017, 8, 1036. [CrossRef] [PubMed]

86. Song, Q.; Liu, H.; Li, C.; Liang, H. miR-33a-5p inhibits the progression of esophageal cancer through the DKK1-mediated Wnt/ $\beta$-catenin pathway. Aging 2021, 13, 1-14. [CrossRef] [PubMed]

87. Fang, Q.; Liu, T.; Yu, C.; Yang, X.; Shao, Y.; Shi, J.; Ye, X.; Zheng, X.; Yan, J.; Xu, D.; et al. LncRNA TUG1 alleviates cardiac hypertrophy by targeting miR-34a/DKK1/Wnt- $\beta$-catenin signalling. J. Cell. Mol. Med. 2020, 24, 3678-3691. [CrossRef]

88. Xiang, J.; Fu, H.Q.; Xu, Z.; Fan, W.; Liu, F.; Chen, B. lncRNA SNHG1 attenuates osteogenic differentiation via the miR-101/DKK1 axis in bone marrow mesenchymal stem cells. Mol. Med. Rep. 2020, 22, 3715-3722. [CrossRef] 
89. Liu, J.U.N.; Wu, M.; Feng, G.; Li, R.U.I.; Wang, Y.; Jiao, J. Downregulation of LINC00707 promotes osteogenic differentiation of human bone marrow-derived mesenchymal stem cells by regulating DKK1 via targeting miR-103a-3p. Int. J. Mol. Med. 2020, 46, 1029-1038. [CrossRef]

90. Zhang, Z.; Liu, J.; Shao, Z.; Pu, F.; Wang, B.; Wu, Q.; Zhang, Y.; Zeng, X.; Guo, X.; Yang, S.; et al. In vitro effect of microRNA-107 targeting Dkk-1 by regulation of Wnt/ $\beta$-catenin signaling pathway in osteosarcoma. Medicine 2017, 96, 27. [CrossRef]

91. Liao, Y.; Jia, X.; Ren, Y.; Deji, Z.; Gesang, Y.; Ning, N.; Feng, H.; Yu, H.; Wei, A. Suppressive role of microRNA-130b-3p in ferroptosis in melanoma cells correlates with DKK1 inhibition and Nrf2-HO-1 pathway activation. Hum. Cell 2021. [CrossRef]

92. Di, G.; Kong, L.; Zhao, Q.; Ding, T. MicroRNA-146a knockdown suppresses the progression of ankylosing spondylitis by targeting dickkopf 1. Biomed. Pharmacother. 2018, 97, 1243-1249. [CrossRef] [PubMed]

93. Xu, Y.; Chen, B.; George, S.K.; Liu, B. Downregulation of MicroRNA-152 contributes to high expression of DKK1 in multiple myeloma. RNA Biol. 2015, 12, 1314-1322. [CrossRef] [PubMed]

94. Zhou, J.; Lin, Y.; Kang, X.; Liu, Z.; Zhang, W.; Xu, F. microRNA-186 in extracellular vesicles from bone marrow mesenchymal stem cells alleviates idiopathic pulmonary fibrosis via interaction with SOX4 and DKK1. Stem Cell Res. Ther. 2021, 12, 96. [CrossRef]

95. Cheng, R.; Lu, C.; Zhang, G.; Zhang, G.; Zhao, G. Overexpression of miR-203 increases the sensitivity of NSCLC A549/H460 cell lines to cisplatin by targeting Dickkopf-1. Oncol. Rep. 2017, 37, 2129-2136. [CrossRef] [PubMed]

96. Xia, Z.; Wang, Y.; Sun, Q.; Du, X. MiR-203 is involved in osteoporosis by regulating DKK1 and inhibiting osteogenic differentiation of MSCs. Eur. Rev. Med. Pharmacol. Sci. 2018, 22, 5098-5105. [CrossRef]

97. Jia, Y.; Chen, L.; Guo, S.; Li, Y. Baicalin induced colon cancer cells apoptosis through miR-217/DKK1-mediated inhibition of Wnt signaling pathway. Mol. Biol. Rep. 2019, 46, 1693-1700. [CrossRef] [PubMed]

98. Jiang, C.; Yu, M.; Xie, X.; Huang, G.; Peng, Y.; Ren, D. miR-217 targeting DKK1 promotes cancer stem cell properties via activation of the Wnt signaling pathway in hepatocellular carcinoma. Oncol. Rep. 2017, 38, 2351-2359. [CrossRef] [PubMed]

99. Dai, Z.; Jin, Y.; Zheng, J.; Liu, K.; Zhao, J.; Zhang, S.; Wu, F.; Sun, Z. MiR-217 promotes cell proliferation and osteogenic differentiation of BMSCs by targeting DKK1 in steroid-associated osteonecrosis. Biomed. Pharmacother. 2019, 109, 1112-1119. [CrossRef] [PubMed]

100. Li, Z.; Hu, H.; Zhang, X.; Liu, G.; Ran, B.; Zhang, P.; Liao, M.; Wu, Y. MiR-291a-3p regulates the BMSCs differentiation via targeting DKK1 in dexamethasone-induced osteoporosis. Kaohsiung J. Med. Sci. 2019, 36, 35-42. [CrossRef]

101. Wu, Z.; Zhang, Y.; Yang, Z.; Zhu, Y.; Xie, Y.; Zhou, F.; Cai, L. Elevation of miR-302b prevents multiple myeloma cell growth and bone destruction by blocking DKK1 secretion. Cancer Cell Int. 2021, 21, 187. [CrossRef]

102. Zhang, Q.; Wang, F.; Wang, F.; Wu, N. Long noncoding RNA MAGI1-IT1 regulates cardiac hypertrophy by modulating miR302e/DKK1/Wnt/beta-catenin signaling pathway. J. Cell. Physiol. 2019, 235, 245-253. [CrossRef]

103. Luan, Y.; Xie, B.; Wei, W. REST-repressed lncRNA NPPA-AS1 regulates cervical cancer progression by modulating miR302e/DKK1/Wnt/ $\beta$-catenin signaling pathway. J. Cell. Biochem. 2021, 122, 16-28. [CrossRef]

104. Li, J.; Feng, Z.; Chen, L.; Wang, X.; Deng, H. MicroRNA-335-5p inhibits osteoblast apoptosis induced by high glucose. Mol. Med. Rep. 2016, 13, 4108-4112. [CrossRef]

105. Lin, S.C.; Wu, H.L.; Yeh, L.Y.; Yang, C.C.; Kao, S.Y.; Chang, K.W. Activation of the mir-371/372/373 mirna cluster enhances oncogenicity and drug resistance in oral carcinoma cells. Int. J. Mol. Sci. 2020, 21, 9442. [CrossRef] [PubMed]

106. Weng, J.; Zhang, H.; Wang, C.; Liang, J.; Chen, G.; Li, W.; Tang, H.; Hou, J. MIR-373-3p Targets DKK1 to Promote EMT-Induced Metastasis via the Wnt/ $\beta$-Catenin Pathway in Tongue Squamous Cell Carcinoma. Biomed. Res. Int. 2017, 2017, 6010926. [CrossRef] [PubMed]

107. Wang, W.; He, Y.; Rui, J.; Xu, M.-Q. miR-410 acts as an oncogene in colorectal cancer cells by targeting dickkopf-related protein 1 via the Wnt/ $\beta$-catenin signaling pathway. Oncol. Lett. 2019, 17, 807-814. [CrossRef]

108. Tang, X.; Lin, J.; Wang, G.; Lu, J. MicroRNA-433-3p promotes osteoblast differentiation through targeting DKK1 expression. PLoS ONE 2017, 12, e0179860. [CrossRef] [PubMed]

109. Wang, F.; Hu, X.-Y.; Cao, C.; Zhao, Y.-W.; He, S.-H. MiR-488 promotes fracture healing by targeting DKK1. Eur. Rev. Med. Pharmacol. Sci. 2018, 22, 8965-8972. [CrossRef] [PubMed]

110. Jia, X.; Li, N.; Peng, C.; Deng, Y.; Wang, J.; Deng, M.; Lu, M.; Yin, J.; Zheng, G.; Liu, H.; et al. miR-493 mediated DKK1 down-regulation confers proliferation, invasion and chemo-resistance in gastric cancer cells. Oncotarget 2016, 7, 7044-7054. [CrossRef]

111. Zhang, H.; Yu, C.; Chen, M.; Li, Z.; Tian, S.; Jiang, J. miR-522 contributes to cell proliferation of hepatocellular carcinoma by targeting DKK1 and SFRP2. Tumor Biol. 2016, 37, 11321-11329. [CrossRef]

112. Zhou, X.; Wang, Y.; Li, Q.; Ma, D.; Nie, A.; Shen, X. Biochemical and Biophysical Research Communications LncRNA Linc-PINT inhibits miR-523-3p to hamper retinoblastoma progression by upregulating Dickkopf-1 (DKK1). Biochem. Biophys. Res. Commun. 2020, 530, 47-53. [CrossRef]

113. Liu, L.; Zuo, Y.; Xu, Y.; Zhang, Z.; Li, Y.; Pang, J. MiR-613 inhibits proliferation and invasion and induces apoptosis of rheumatoid arthritis synovial fibroblasts by direct downregulation of DKK1. Cell. Mol. Biol. Lett. 2019, 24, 8. [CrossRef] [PubMed]

114. Wang, C.; Liao, H.; Zhang, Y.; Cao, Z. MicroRNA-3064-3p regulates the differentiation of cementoblasts through targeting DKK1. J. Periodontal Res. 2018, 53, 705-713. [CrossRef] [PubMed] 
115. Yao, Y.; Hua, Q.; Zhou, Y. CircRNA has_circ_0006427 suppresses the progression of lung adenocarcinoma by regulating miR6783-3p/DKK1 axis and inactivating Wnt/ $\beta$-catenin signaling pathway. Biochem. Biophys. Res. Commun. 2018, 508, 37-45. [CrossRef]

116. Yao, Y.; Zhou, Y.; Hua, Q. circRNA hsa_circ_0018414 inhibits the progression of LUAD by sponging miR-6807-3p and upregulating DKK1. Mol. Ther. Nucleic Acid 2021, 23, 783-796. [CrossRef]

117. Min, K.; Lee, S.K. EBV miR-BART10-3p Promotes Cell Proliferation and Migration by Targeting DKK1. Int. J. Biol. Sci. 2019, 15, 657-667. [CrossRef]

118. Dong, M.; Gong, L.; Chen, J.; Zhang, X.; Zhang, Y.; Hui, D. EBV-miR-BART10-3p and EBV-miR-BART22 promote metastasis of EBV-associated gastric carcinoma by activating the canonical Wnt signaling pathway. Cell. Oncol. 2020, 43, 901-913. [CrossRef] [PubMed]

119. Kumaresan, M.; Mysore, V. Controversies in Hair Transplantation. Muthuvel Kumaresan Venkatram Mysore 2018, 11, $173-181$. [CrossRef] [PubMed]

120. Suchonwanit, P.; Thammarucha, S.; Leerunyakul, K. Minoxidil and its use in hair disorders: A review. Drug Des. Dev. Ther. 2019, 13, 2777-2786. [CrossRef]

121. Panchaprateep, R.; Lueangarun, S. Efficacy and safety of oral minoxidil $5 \mathrm{mg}$ once daily in the treatment of male patients with androgenetic alopecia: An open-label and global photographic assessment. Dermatol. Ther. 2020, 10, 1345-1357. [CrossRef]

122. Yano, K.; Brown, L.F.; Detmar, M. Control of hair growth and follicle size by VEGF-mediated angiogenesis. J. Clin. Investig. 2001, 107, 409-417. [CrossRef]

123. Kwack, M.H.; Kang, B.M.; Kim, M.K.; Kim, J.C.; Sung, Y.K. Minoxidil activates $\beta$-catenin pathway in human dermal papilla cells: A possible explanation for its anagen prolongation effect. J. Dermatol. Sci. 2011, 62, 154-159. [CrossRef] [PubMed]

124. Choi, N.; Shin, S.; Song, S.U.; Sung, J. Minoxidil Promotes Hair Growth through Stimulation of Growth Factor Release from Adipose-Derived Stem Cells. Int. J. Mol. Sci. 2018, 19, 691. [CrossRef]

125. Andy, G.; John, M.; Mirna, S.; Rachita, D.; Michael, K.; Maja, K.; Aseem, S.; Zeljana, B. Controversies in the treatment of androgenetic alopecia: The history of finasteride. Dermatol. Ther. 2019, 32, e12647. [CrossRef] [PubMed]

126. Kim, J.; Na, J.; Bak, D.H.O.; Lee, B.C.; Lee, E.; Choi, M.I.J.I.; Ryu, C.H.O.; Lee, S.; Mun, S.K.; Park, B.C.; et al. Development of finasteride polymer microspheres for systemic application in androgenic alopecia. Int. J. Mol. Med. 2019, 43, $2409-2419$. [CrossRef] [PubMed]

127. Reichenberg, J.S.; Kelsey, P.A.; Therrien, C.A.; Gavino, C.; Reichenberg, J.S. Adverse effects and safety of 5-alpha reductase inhibitors (finasteride, dutasteride): A systematic review. J. Clin. Aesthet. Dermatol. 2016, 9, 56-62.

128. Arif, T.; Dorjay, K.; Adil, M.; Sami, M. Dutasteride in Androgenetic Alopecia: An Update. Curr. Clin. Pharmacol. 2017, 12, 31-35. [CrossRef] [PubMed]

129. York, K.; Meah, N.; Bhoyrul, B.; Sinclair, R.; York, K.; Meah, N.; Bhoyrul, B.; Sinclair, R.; York, K.; Meah, N.; et al. Expert Opinion on Pharmacotherapy Treatment review for male pattern hair-loss Treatment review for male pattern hair-loss. Expert Opin. Pharmacother. 2020, 21, 603-612. [CrossRef] [PubMed]

130. Motofei, I.G.; Rowland, D.L.; Tampa, M.; Sarbu, M.-I.; Mitran, M.-I.; Mitran, C.-I.; Stoian, A.P.; Diaconu, C.C.; Paunica, S.; Georgescu, S.R. Finasteride and androgenic alopecia; from therapeutic options to medical implications. J. Dermatolog. Treat. 2019, 31, 415-421. [CrossRef]

131. Marihart, S.; Harik, M.; Djavan, B. Dutasteride: A Review of Current Data on a Novel Dual Inhibitor of. Rev. Urol. 2005, 7, 203-210.

132. Zhou, Z.; Song, S.; Gao, Z.; Wu, J.; Ma, J.; Cui, Y. The efficacy and safety of dutasteride compared with finasteride in treating men with androgenetic alopecia: A systematic review and meta-analysis. Clin. Interv. Aging 2019, 14, 399-406. [CrossRef] [PubMed]

133. Ahmed, N.S.; Ghatak, S.; El Masry, M.S.; Gnyawali, S.C.; Roy, S.; Amer, M.; Everts, H.; Sen, C.K.; Khanna, S. Epidermal E-Cadherin Dependent $\beta$-Catenin Pathway Is Phytochemical Inducible and Accelerates Anagen Hair Cycling. Mol. Ther. 2017, 25, $2502-2512$. [CrossRef] [PubMed]

134. Hamblin, M.R. NIH Public Access. Laser Surg. Med. 2014, 46, 144-151. [CrossRef]

135. Wang, B.; Liao, P.P.; Liu, L.H.; Fang, X.; Li, W.; Guan, S.M. Baicalin and geniposide inhibit the development of atherosclerosis by increasing Wnt1 and inhibiting dickkopf-related protein-1 expression. J. Geriatr. Cardiol. 2016, 13, 846-854. [CrossRef]

136. Bejaoui, M.; Villareal, M.O.; Isoda, H. $\beta$-catenin-mediated hair growth induction effect of 3,4,5-tri-O-caffeoylquinic acid. Aging 2019, 11, 4216-4237. [CrossRef] [PubMed]

137. Kang, J.I.; Choi, Y.K.; Koh, Y.S.; Hyun, J.W.; Kang, J.H.; Lee, K.S.; Lee, C.M.; Yoo, E.S.; Kang, H.K. Vanillic acid stimulates anagen signaling via the PI3K/Akt/ $\beta$-catenin pathway in dermal papilla cells. Biomol. Ther. 2020, 28, 354-360. [CrossRef]

138. Lim, K.M.; An, S.; Lee, O.K.; Lee, M.J.; Lee, J.P.; Lee, K.S.; Lee, G.T.; Lee, K.K.; Bae, S. Analysis of changes in microRNA expression profiles in response to the troxerutin-mediated antioxidant effect in human dermal papilla cells. Mol. Med. Rep. 2015, 12, 2650-2660. [CrossRef]

139. Ohn, J.; Been, K.W.; Kim, J.Y.; Kim, E.J.; Park, T.; Yoon, H.; Ji, J.S.; Okada-iwabu, M.; Iwabu, M.; Yamauchi, T.; et al. Discovery of a transdermally deliverable pentapeptide for activating AdipoR1 to promote hair growth. EMBO Mol. Med. 2021, 13, e13790. [CrossRef] [PubMed] 
140. Rajendran, R.L.; Gangadaran, P.; Bak, S.S.; Oh, J.M.; Kalimuthu, S.; Lee, H.W.; Baek, S.H.; Zhu, L.; Sung, Y.K.; Jeong, S.Y.; et al. Extracellular vesicles derived from MSCs activates dermal papilla cell in vitro and promotes hair follicle conversion from telogen to anagen in mice. Sci. Rep. 2017, 7, 15560. [CrossRef]

141. Castro, A.R.; Logarinho, E. Tissue engineering strategies for human hair follicle regeneration: How far from a hairy goal? Concise review. Stem Cells Transl. Med. 2020, 9, 342-350. [CrossRef]

142. Zhao, J.; Lin, H.; Wang, L.; Guo, K.; Jing, R.; Li, X. Suppression of FGF5 and FGF18 Expression by Cholesterol-Modified siRNAs Promotes Hair Growth in Mice. Front. Pharmacol. 2021, 12, 666860. [CrossRef] [PubMed]

143. Kwack, M.H.; Seo, C.H.; Gangadaran, P.; Ahn, B.C.; Kim, M.K.; Kim, J.C.; Sung, Y.K. Exosomes derived from human dermal papilla cells promote hair growth in cultured human hair follicles and augment the hair-inductive capacity of cultured dermal papilla spheres. Exp. Dermatol. 2019, 28, 854-857. [CrossRef] [PubMed]

144. Rajagopal, C.; Harikumar, K.B. The origin and functions of exosomes in cancer. Front. Oncol. 2018, 8, 66. [CrossRef]

145. Wojciechowska, A.; Braniewska, A.; Kozar-kaminska, K. MicroRNA in cardiovascular biology and disease. Adv. Clin. Exp. Med. 2017, 26, 865-874. [CrossRef] [PubMed]

146. Treiber, T.; Treiber, N.; Meister, G. Regulation of microRNA biogenesis and its crosstalk with other cellular pathways. Nat. Rev. Mol. Cell Biol. 2019, 20, 5-20. [CrossRef]

147. Brien, J.O.; Hayder, H.; Zayed, Y.; Peng, C. Overview of microRNA biogenesis, mechanisms of actions, and circulation. Front. Endocrinol. 2018, 9, 402. [CrossRef] [PubMed]

148. Lewis, B.P.; Shih, I.; Jones-rhoades, M.W.; Bartel, D.P.; Burge, C.B. Prediction of Mammalian MicroRNA Targets. Cell 2003, 115, 787-798. [CrossRef]

149. Andl, T.; Murchison, E.P.; Liu, F.; Zhang, Y.; Yunta-gonzalez, M.; Tobias, J.W.; Andl, C.D.; Seykora, J.T.; Hannon, G.J.; Millar, S.E. Report The miRNA-Processing Enzyme Dicer Is Essential for the Morphogenesis and Maintenance of Hair Follicles. Curr. Biol. 2006, 16, 1041-1049. [CrossRef]

150. Deng, W.; Hu, T.; Han, L.; Liu, B.; Tang, X.; Chen, H.; Chen, X.; Wan, M. miRNA microarray profiling in patients with androgenic alopecia and the effects of miR-133b on hair growth. Exp. Mol. Pathol. 2021, 118, 104589. [CrossRef]

151. Goodarzi, H.R.; Abbasi, A.; Saffari, M.; Fazelzadeh Haghighi, M.; Tabei, M.B.; Noori Daloii, M.R. Differential expression analysis of balding and nonbalding dermal papilla microRNAs in male pattern baldness with a microRNA amplification profiling method. Br. J. Dermatol. 2012, 166, 1010-1016. [CrossRef]

152. Bernard, B.A. Advances in Understanding Hair Growth. F1000Research 2016, 5, F1000. [CrossRef]

153. Iwamoto, N.; Fukui, S.; Takatani, A.; Shimizu, T.; Umeda, M.; Nishino, A.; Igawa, T.; Koga, T.; Kawashiri, S.; Ichinose, K.; et al. Osteogenic differentiation of fibroblast-like synovial cells in rheumatoid arthritis is induced by microRNA-218 through a ROBO/Slit pathway. Arthritis Res. Ther. 2018, 20, 189. [CrossRef] [PubMed]

154. Li, Y.C.; Pirro, A.E.; Amling, M.; Delling, G.; Baron, R.; Bronson, R.; Demay, M.B. Targeted ablation of the vitamin D receptor: An animal model of vitamin D-dependent rickets type II with alopecia. Proc. Natl. Acad. Sci. USA 1997, 94, 9831-9835. [CrossRef] [PubMed]

155. Lisse, T.S.; Saini, V.; Zhao, H.; Luderer, H.F.; Gori, F.; Demay, M.B. The Vitamin D Receptor Is Required for Activation of cWnt and Hedgehog Signaling in Keratinocytes. Mol. Endocrinol. 2014, 28, 1698-1706. [CrossRef]

156. Yi, R.; O'Carroll, D.; Pasolli, H.A.; Zhang, Z.; Dietrich, F.S.; Tarakhovsky, A.; Fuchs, E. Morphogenesis in skin is governed by discrete sets of differentially expressed microRNAs. Nat. Genet. 2006, 38, 356-362. [CrossRef] [PubMed]

157. Ma, T.; Li, J.; Jiang, Q.; Wu, S.; Jiang, H.; Zhang, Q. Differential expression of miR-let7a in hair follicle cycle of Liaoning cashmere goats and identification of its targets. Funct. Integr. Genom. 2018, 18, 701-707. [CrossRef]

158. Liu, N.; Niu, S.; Cao, X.-R.; Cheng, J.-Q.; Gao, S.-Y.; Yu, X.-J.; Wang, H.-D.; Dong, C.-S.; He, X.-Y. Let-7b regulates alpaca hair growth by downregulating ectodysplasin A. Mol. Med. Rep. 2018, 17, 4688-4694. [CrossRef] [PubMed]

159. Zhai, B.; Zhang, L.; Wang, C.; Zhao, Z.; Zhang, M.; Li, X. Identification of microRNA-21 target genes associated with hair follicle development in sheep. PeerJ 2019, 7, e7167. [CrossRef]

160. Cai, B.; Li, M.; Zheng, Y.; Yin, Y.; Jin, F.; Li, X.; Dong, J.; Liu, X.; Zhang, K.; Li, D.; et al. EZH2-mediated inhibition of microRNA-22 promotes differentiation of hair follicle stem cells by elevating STK40 expression. Aging 2020, 12, 12726-12739. [CrossRef]

161. Yuan, S.; Li, F.; Meng, Q.; Zhao, Y.; Chen, L.; Zhang, H.; Xue, L.; Zhang, X.; Lengner, C.; Yu, Z. Post-transcriptional Regulation of Keratinocyte Progenitor Cell Expansion, Differentiation and Hair Follicle Regression by miR-22. PLoS Genet. 2015, 11, e1005253. [CrossRef]

162. Amelio, I.; Lena, A.M.; Bonanno, E.; Melino, G.; Candi, E. miR-24 affects hair follicle morphogenesis targeting Tcf-3. Cell Death Dis. 2013, 4, e922. [CrossRef]

163. Liu, F.; Zhang, X.; Peng, Y.; Zhang, L.; Yu, Y.; Hua, P.; Zhu, P.; Yan, X.; Li, Y. miR-24 controls the regenerative competence of hair follicle progenitors by targeting Plk3. Cell Rep. 2021, 35, 109225. [CrossRef] [PubMed]

164. Kapinas, K.; Kessler, C.; Ricks, T.; Gronowicz, G.; Delany, A.M. miR-29 modulates Wnt signaling in human osteoblasts through a positive feedback loop*. J. Biol. Chem. Chem. 2010, 285, 25221-25231. [CrossRef]

165. Kapinas, K.; Kessler, C.B.; Delany, A.M. miR-29 Suppression of Osteonectin in Osteoblasts: Regulation During Differentiation and by Canonical Wnt Signaling. J. Cell. Biochem. 2009, 108, 216-224. [CrossRef]

166. Hsu, Y.; Chang, P.; Ho, C.; Huang, Y.; Shih, Y. Protective effects of miR-29a on diabetic glomerular dysfunction by modulation of DKK1/Wnt/ $\beta$-catenin signaling. Sci. Rep. 2016, 6, 30575. [CrossRef] [PubMed] 
167. Zhu, N.; Lin, E.; Zhang, H.; Liu, Y.; Cao, G.; Fu, C. LncRNA H19 Overexpression Activates Wnt Signaling to Maintain the Hair Follicle Regeneration Potential of Dermal Papilla Cells. Front. Genet. 2020, 11, 694. [CrossRef] [PubMed]

168. Ge, M.; Liu, C.; Li, L.; Lan, M.; Yu, Y.; Gu, L.; Su, Y.; Zhang, K.; Zhang, Y.; Wang, T.; et al. miR-29a/b1 Inhibits Hair Follicle Stem Cell Lineage Progression by Spatiotemporally Suppressing WNT and BMP Signaling. Cell Rep. 2019, 29, 2489-2504. [CrossRef]

169. Feng, Y.; Wang, J.; Ma, J.; Zhang, L.; Chu, C.; Hu, H.; Wang, Y.; Li, Y. miR-31-5p promotes proliferation and inhibits apoptosis of goat hair follicle stem cells by targeting RASA1/MAP3K1 pathway. Exp. Cell Res. 2021, 398, 112441. [CrossRef]

170. Mardaryev, A.N.; Ahmed, M.I.; Vlahov, N.V.; Fessing, M.Y.; Gill, J.H.; Sharov, A.A.; Botchkareva, N.V. Micro-RNA-31 controls hair cycle-associated changes in gene expression programs of the skin and hair follicle. FASEB J. 2010, 24, 3869-3881. [CrossRef]

171. Chen, X.; Zhong, L.; Li, X.; Liu, W.; Zhao, Y.; Li, J. Down-regulation of microRNA-31-5p inhibits proliferation and invasion of osteosarcoma cells through Wnt/ $\beta$-catenin signaling pathway by enhancing AXIN1. Exp. Mol. Pathol. 2019, 108, 32-41. [CrossRef]

172. Luan, L.; Shi, J.; Yu, Z.; Andl, T. The major miR-31 target genes STK40 and LATS2 and their implications in the regulation of keratinocyte growth and hair differentiation. Exp. Dermatol. 2017, 26, 497-504. [CrossRef] [PubMed]

173. Wang, S.; Kobeissi, A.; Dong, Y.; Kaplan, N.; Yang, W.; He, C. MicroRNAs-103/107 Regulate Autophagy in the Epidermis. J. Investig. Dermatol. 2018, 138, 1481-1490. [CrossRef]

174. Mokabber, H.; Najafzadeh, N.; Vardi, M.M. miR-124 promotes neural differentiation in mouse bulge stem cells by repressing Ptbp1 and Sox9. J. Cell. Physiol. 2019, 234, 8941-8950. [CrossRef] [PubMed]

175. Peng, T.; Peng, J.J.; Miao, G.Y.; Tan, Z.Q.; Liu, B.; Zhou, E. miR-125/CDK2 axis in cochlear progenitor cell proliferation. Mol. Med. Rep. 2021, 23, 102. [CrossRef] [PubMed]

176. Wu, Z.; Hai, E.; Di, Z.; Ma, R.; Shang, F.; Wang, M.; Liang, L.; Rong, Y.; Pan, J.; Su, R.; et al. Chi-miR-130b-3p regulates Inner Mongolia cashmere goat skin hair follicles in fetuses by targeting Wnt family member 10A. G3 Genes Genomes Genet. 2021, 11, jkaa023. [CrossRef]

177. Ding, Y.; Xue, X.; Liu, Z.; Ye, Y.; Xiao, P.; Pu, Y. Expression Profiling and Functional Characterization of miR-26a and miR-130a in Regulating Zhongwei Goat Hair Development via the TGF- $\beta$ /SMAD Pathway. Int. J. Mol. Sci. 2020, 21, 5076. [CrossRef]

178. Chen, Y.; Huang, J.; Liu, Z.; Chen, R.; Fu, D.; Yang, L.; Wang, J.; Du, L.; Wen, L.; Miao, Y.; et al. miR-140-5p in Small Extracellular Vesicles from Human Papilla Cells Stimulates Hair Growth by Promoting Proliferation of Outer Root Sheath and Hair Matrix Cells. Front. Cell Dev. Biol. 2020, 8, 593638. [CrossRef] [PubMed]

179. Lv, X.; Gao, W.; Jin, C.; Wang, L.; Wang, Y.; Chen, W.; Zou, S.; Huang, S.; Li, Z.; Wang, J.; et al. Preliminary study on microR-148a and microR-10a in dermal papilla cells of Hu sheep. BMC Genet. 2019, 20, 1-12. [CrossRef] [PubMed]

180. Yang, W.; Li, Q.; Su, B.; Yu, M. MicroRNA-148b promotes proliferation of hair follicle cells by targeting NFAT5. Front. Agric. Sci. Eng. 2016, 3, 72-80. [CrossRef]

181. Wang, J.; Qu, J.; Li, Y.; Feng, Y.; Ma, J.; Zhang, L.; Chu, C.; Hu, H.; Wang, Y.; Ji, D. miR-149-5p Regulates Goat Hair Follicle Stem Cell Proliferation and Apoptosis by Targeting the CMTM3/AR Axis During Superior-Quality Brush Hair Formation. Front. Genet. 2020, 11, 529757. [CrossRef] [PubMed]

182. Mahmoudian-Sani, M.R.; Jami, M.S.; Mahdavinezhad, A.; Amini, R.; Farnoosh, G.; Saidijam, M. The effect of the microRNA-183 family on hair cell-specific markers of human bone marrow-derived mesenchymal stem cells. Audiol. Neurotol. 2018, 23, 208-215. [CrossRef]

183. Zhou, W.E.I.; Du, J.; Jiang, D.I.; Wang, X.; Chen, K.; Tang, H. microRNA-183 is involved in the differentiation and regeneration of Notch signaling-prohibited hair cells from mouse cochlea. Mol. Med. Rep. 2018, 18, 1253-1262. [CrossRef] [PubMed]

184. Kim, C.W.; Han, J.H.; Wu, L.; Choi, J.Y. microRNA-183 is Essential for Hair Cell Regeneration after Neomycin Injury in Zebrafish. Yonsei Med. J. 2018, 59, 141-147. [CrossRef] [PubMed]

185. Liu, Z.; Yang, F.; Zhao, M.; Ma, L.; Li, H.; Xie, Y.; Nai, R. The intragenic mRNA-microRNA regulatory network during telogenanagen hair follicle transition in the cashmere goat. Sci. Rep. 2018, 8, 14227. [CrossRef]

186. Zhu, N.; Huang, K.; Liu, Y.; Zhang, H.; Lin, E.; Zeng, Y.; Li, H.; Xu, Y.; Cai, B.; Yuan, Y.; et al. miR-195-5p Regulates Hair Follicle Inductivity of Dermal Papilla Cells by Suppressing Wnt/ $\beta$-Catenin Activation. Biomed. Res. Int. 2018, 2018, 4924356. [CrossRef] [PubMed]

187. Hoefert, J.E.; Bjerke, G.A.; Wang, D.; Yi, R. The microRNA-200 family coordinately regulates cell adhesion and proliferation in hair morphogenesis. J. Cell Biol. 2018, 217, 2185-2204. [CrossRef]

188. Warshauer, E.; Samuelov, L.; Sarig, O.; Vodo, D.; Bindereif, A.; Kanaan, M.; Gat, U.; Fuchs-telem, D.; Shomron, N.; Farberov, L.; et al. RBM28, a protein deficient in ANE syndrome, regulates hair follicle growth via miR-203 and p63. Exp. Dermatol. 2015, 24, 618-622. [CrossRef] [PubMed]

189. Ma, T.; Li, J.; Li, J.; Wu, S.; Jiang, H. Expression of miRNA-203 and its target gene in hair follicle cycle development of Cashmere goat. Cell Cycle 2021, 20, 204-210. [CrossRef]

190. Luo, Z.; Dou, J.; Xie, F.; Lu, J.; Han, Q. miR-203a-3p promotes loureirin A-induced hair follicle stem cells differentiation by targeting Smad1. Anat. Rec. 2020, 304, 531-540. [CrossRef]

191. Liu, G.; Li, S.; Liu, H.; Zhu, Y.; Bai, L.; Sun, H.; Gao, S.; Jiang, W.; Li, F. The functions of ocu-miR-205 in regulating hair follicle development in Rex rabbits. BMC Dev. Biol. 2020, 20, 8. [CrossRef] [PubMed]

192. Du, K.T.; Deng, J.Q.; He, X.G.; Liu, Z.p.; Peng, C.; Zhang, M.S. MiR-214 Regulates the Human Hair Follicle Stem Cell Proliferation and Differentiation by Targeting EZH2 and Wnt/ $\beta$-Catenin Signaling Way In Vitro. Tissue Eng. Regen. Med. 2018, 15, 341-350. [CrossRef] [PubMed] 
193. Jin, F.; Li, M.; Li, X.; Zheng, Y.; Zhang, K.; Liu, X.; Cai, B.; Yin, G. DNMT1-mediated methylation inhibits microRNA-214-3p and promotes hair follicle stem cell differentiate into adipogenic lineages. Stem Cell Res. Ther. 2020, 11, 1-12. [CrossRef]

194. Mohammadi, P.; Ali, M.; Kass, K.; Shari, A.; Moradi, S.; Khosravani, P.; Aghdami, R.; Taheri, P.; Hosseini, G.; Baharvand, H.; et al. Defining microRNA signatures of hair follicular stem and progenitor cells in healthy and androgenic alopecia patients. J. Dermatol. Sci. 2021, 101, 49-57. [CrossRef]

195. Aksenenko, M.; Palkina, N.; Komina, A.; Ruksha, T. MiR-92a-1-5p and miR-328-3p Are Up-Regulated in Skin of Female Pattern Hair Loss Patients. Ann. Dermatol. 2019, 31, 256-259. [CrossRef] [PubMed]

196. Lin, B.J.; Lin, G.Y.; Zhu, J.Y.; Yin, G.Q.; Huang, D.; Yan, Y.Y. LncRNA-PCAT1 maintains characteristics of dermal papilla cells and promotes hair follicle regeneration by regulating miR-329/Wnt10b axis. Exp. Cell Res. 2020, 394, 112031. [CrossRef]

197. Hai, E.; Han, W.; Wu, Z.; Ma, R.; Shang, F.; Wang, M.; Liang, L.; Rong, Y.; Pan, J.; Wang, Z.; et al. Chi-miR-370-3p regulates hair follicle morphogenesis of Inner Mongolian cashmere goats. G3 Genes Genomes Genet. 2021, 11, jkab091. [CrossRef]

198. Lin, B.; Zhu, J.; Ye, J.; Lu, S.; Liao, M.; Meng, X. LncRNA-XIST promotes dermal papilla induced hair follicle regeneration by targeting miR-424 to activate hedgehog signaling. Cell. Signal. 2020, 72, 109623. [CrossRef]

199. Kriegel, A.J.; Liu, Y.; Fang, Y.; Ding, X.; Liang, M.; Kriegel, A.J.; Liu, Y.; Fang, Y.; Ding, X.; Liang, M. The miR-29 family: Genomics, cell biology, and relevance to renal and cardiovascular injury. Physiol. Genom. 2012, 44, 237-244. [CrossRef] [PubMed]

200. Navasardyan, I.; Bonavida, B. Chapter 8-YY1 Is Involved in the Pathogenesis and Malignant Properties of Human TripleNegative Breast Cancer (TNBC). In YY1 in the Control of the Pathogenesis and Drug Resistance of Cancer: A Critical Therapeutic Target; Bonavida, B., Ed.; Academic Press: Cambridge, MA, USA, 2021; ISBN 9780128219096.

201. Lin, P.-C.; Chiu, Y.-L.; Banerjee, S.; Park, K.; Mosquera, J.M.; Giannopoulou, E.; Alves, P.; Tewari, A.K.; Gerstein, M.B.; Beltran, H.; et al. Epigenetic repression of miR-31 disrupts androgen receptor homeostasis and contributes to prostate cancer progression. Cancer Res. 2014, 73, 1232-1244. [CrossRef]

202. Hibberts, N.A.; Howell, A.E.; Randall, V.A. Balding hair follicle dermal papilla cells contain higher levels of androgen receptors than those from non-balding scalp. J. Endocrinol. 1998, 156, 59-65. [CrossRef] [PubMed]

203. Ellis, J.A.; Stebbing, M.; Harrap, S.B. Polymorphism of the Androgen Receptor Gene is Associated with Male Pattern Baldness. J. Investig. Dermatol. 2001, 116, 452-455. [CrossRef]

204. Kim, B.K.; Yoon, S.K. Hairless Up-Regulates Tgf- $\beta 2$ Expression via Down-Regulation of miR-31 in the Skin of "Hairpoor" (Hr ${ }^{H p}$ ) Mice. J. Cell. Physiol. 2015, 230, 2075-2085. [CrossRef]

205. Yu, T.; Ma, P.; Wu, D.; Shu, Y.; Gao, W. Functions and mechanisms of microRNA-31 in human cancers. Biomed. Pharmacother. 2018, 108, 1162-1169. [CrossRef] [PubMed]

206. Tian, Y.; Ma, X.; Lv, C.; Sheng, X.; Li, X.; Zhao, R.; Song, Y.; Andl, T.; Plikus, M.V.; Sun, J.; et al. Stress responsive miR-31 is a major modulator of mouse intestinal stem cells during regeneration and tumorigenesis. Elife 2017, 6, e29538. [CrossRef]

207. Yu, Y.; Zhang, X.; Liu, F.; Zhu, P.; Zhang, L.; Peng, Y.; Yan, X.; Li, Y.; Hua, P.; Liu, C.; et al. A stress-induced miR-31-CLOCK-ERK pathway is a key driver and therapeutic target for skin aging. Nat. Aging 2021, 1, 795-809. [CrossRef]

208. Mourelatos, Z.; Paushkin, S.; Sharma, A.; Charroux, B.; Abel, L.; Rappsilber, J.; Mann, M.; Dreyfuss, G. miRNPs: A novel class of ribonucleoproteins containing numerous microRNAs. Genes Dev. 2002, 16, 720-728. [CrossRef] [PubMed]

209. Zhao, X.; Sun, S.; Xu, J.; Luo, Y.; Xin, Y.; Wang, Y. MicroRNA-152 inhibits cell proliferation of osteosarcoma by directly targeting Wnt/ $\beta$-catenin signaling pathway in a DKK1-dependent manner. Oncol. Rep. 2018, 40, 767-774. [CrossRef]

210. Owens, P.; Han, G.; Li, A.G.; Wang, X. The Role of Smads in Skin Development. J. Investig. Dermatol. 2008, 128, 783-790. [CrossRef] [PubMed]

211. Taipaleenmäki, H.; Farina, N.H.; Van Wijnen, A.J.; Stein, L.; Hesse, E.; Stein, G.S.; Lian, J.B. Antagonizing miR-218-5p attenuates Wnt signaling and reduces metastatic bone disease of triple negative breast cancer cells. Oncotarget 2016, 7, 79032-79046. [CrossRef]

212. Wu, Z.; Han, Y.; Li, Y.; Li, X.; Sun, T.; Chen, G. miR-218-5p inhibits the stem cell properties and invasive ability of the A2B5+CD133subgroup of human glioma stem cells. Oncol. Rep. 2016, 35, 869-877. [CrossRef]

213. Li, X.; He, J.; Shao, M.; Cui, B.; Peng, F.; Li, J.; Ran, Y.; Jin, D. Biomedicine \& pharmacotherapy downregulation of miR-218-5p promotes invasion of oral squamous cell carcinoma cells via activation of CD44-ROCK signaling. Biomed. Pharmacother. 2018, 106, 646-654. [CrossRef] [PubMed]

214. Peng, P.; Chen, T.; Wang, Q.; Zhang, Y.; Zheng, F.; Huang, S.; Tang, Y.; Yang, C.; Ding, W.; Ren, D.; et al. Decreased miR-218-5p Levels as a Serum Biomarker in Bone Metastasis of Prostate Cancer. Oncol. Res. Treat. 2019, 42, 165-185. [CrossRef]

215. Xia, C.; Jiang, H.; Ye, F.; Zhuang, Z. The Multifunction Of miR-218-5p-Cx43 Axis in Breast Cancer. OncoTargets Ther. 2019, 12, 8319-8328. [CrossRef]

216. Son, S.W.; Lee, H.Y.; Moeng, S.; Kuh, H.J.; Choi, S.Y.; Park, J.K. Participation of microRNAs in the treatment of cancer with phytochemicals. Molecules 2020, 25, 4701. [CrossRef] [PubMed]

217. Roberts, T.C.; Langer, R.; Wood, M.J.A. Advances in oligonucleotide drug delivery. Nat. Rev. Drug Discov. 2020, 19, 673-694. [CrossRef] [PubMed]

218. Brown, R.A.M.; Richardson, K.L.; Kalinowski, F.C.; Epis, M.R.; Horsham, J.L.; Kabir, T.D.; De Pinho, M.H.; Beveridge, D.J.; Stuart, L.M.; Wintle, L.C.; et al. Evaluation of MicroRNA Delivery In Vivo. Methods Mol. Biol. 2018, 1699, 155-178. [CrossRef]

219. Bajan, S.; Hutvagner, G. RNA-Based Therapeutics: From Antisense Oligonucleotides to miRNAs. Cells 2020, 9, 137. [CrossRef] 
220. Ibrahim, A.F.; Weirauch, U.; Thomas, M. MicroRNA Replacement Therapy for miR-145 and miR-33a Is Efficacious in a Model of Colon Carcinoma Is Efficacious in a Model of Colon Carcinoma. Cancer Res. 2011, 71, 5214-5224. [CrossRef] [PubMed]

221. Yang, N. An overview of viral and nonviral delivery systems for microRNA. Int. J. Pharm. Investig. 2015, 5, 179-181. [CrossRef]

222. Sun, X.; Guo, Q.; Wei, W.; Robertson, S.; Yuan, Y.; Luo, X. Current Progress on MicroRNA-Based Gene Delivery in the Treatment of Osteoporosis and Osteoporotic Fracture. Int. J. Endocrinol. 2019, 2019, 6782653. [CrossRef] [PubMed]

223. Gasparello, J.; Lomazzi, M.; Papi, C.; Aversa, E.D.; Sansone, F.; Casnati, A.; Donofrio, G.; Gambari, R.; Finotti, A. Efficient Delivery of MicroRNA and AntimiRNA Molecules Using an Argininocalix[4]arene Macrocycle. Mol. Ther. Nucleic Acid 2019, 18, 748-763. [CrossRef]

224. Gasparello, J.; Manicardi, A.; Casnati, A.; Corradini, R.; Gambari, R.; Finotti, A.; Sansone, F. Efficient cell penetration and delivery of peptide nucleic acids by an argininocalix[4]arene. Sci. Rep. 2019, 9, 3036. [CrossRef]

225. Cheng, X.; Lee, R.J. The role of helper lipids in lipid nanoparticles (LNPs) designed for oligonucleotide delivery. Adv. Drug Deliv. Rev. 2016, 99, 129-137. [CrossRef] [PubMed]

226. Wei, S.; Lee, L.; Paoletti, C.; Campisi, M.; Osaki, T.; Adriani, G.; Kamm, R.D.; Mattu, C.; Chiono, V. MicroRNA delivery through nanoparticles. J. Control. Release 2019, 313, 80-95. [CrossRef]

227. Gokita, K.; Inoue, J.; Ishihara, H.; Kojima, K.; Inazawa, J. Therapeutic Potential of LNP-Mediated Delivery of miR-634 for Cancer Therapy. Mol. Ther. Nucleic Acids 2020, 19, 330-338. [CrossRef]

228. Shi, S.; Han, L.; Gong, T.; Zhang, Z.; Sun, X. Systemic Delivery of microRNA-34a for Cancer Stem Cell Therapy. Angew. Chem. Int. Ed. Engl. 2013, 52, 3901-3905. [CrossRef]

229. Schoenmaker, L.; Witzigmann, D.; Kulkarni, J.A.; Verbeke, R.; Kersten, G.; Jiskoot, W.; Crommelin, D.J.A. mRNA-lipid nanoparticle COVID-19 vaccines: Structure and stability. Int. J. Pharm. 2021, 601, 120586. [CrossRef] [PubMed]

230. Fan, J.; Feng, Y.; Zhang, R.; Zhang, W.; Shu, Y.; Zeng, Z.; Huang, S.; Zhang, L.; Huang, B.; Wu, D.; et al. A simplified system for the effective expression and delivery of functional mature microRNAs in mammalian cells. Cancer Gene Ther. 2020, 27, 424-437. [CrossRef] [PubMed]

231. Dasgupta, I.; Chatterjee, A. Recent advances in miRNA delivery systems. Methods Protoc. 2021, 4, 10. [CrossRef] [PubMed]

232. Zhao, Y.; Li, X.; Zhang, W.; Yu, L.; Wang, Y.; Deng, Z.; Liu, M.; Mo, S.; Wang, R.; Zhao, J.; et al. Trends in the biological functions and medical applications of extracellular vesicles and analogues. Acta Pharm. Sin. B 2021, 11, 2114-2135. [CrossRef] 